\title{
Early and Middle Miocene dinoflagellate cyst stratigraphy of the Central Paratethys, Central Europe
}

\author{
GONZALO JIMÉNEZ-MORENO ${ }^{1,2}$, MARTIN J. HEAD ${ }^{3}$ \& MATHIAS HARZHAUSER ${ }^{4}$ \\ ${ }^{1}$ Departamento de Estratigrafía y Paleontología, Universidad de Granada, Fuente Nueva s/n, 18002 Granada, Spain \\ ${ }^{2}$ Laboratoire PaléoEnvironnements et PaléobioSphère (UMR CNRS 5125), Université Cl. Bernard - Lyon 1, $27-43$ boulevard du 11 Novembre, \\ 69622 Villeurbanne, France (Current address: Department of Earth and Planetary Sciences, Northrop Hall, University of New Mexico, \\ Albuquerque, New Mexico 87131 and Center for Environmental Sciences \& Education, Box 5694, Northern Arizona University, Flagstaff, \\ AZ 86011, USA (e-mail: Gonzalo.Jimenez-Moreno@NAU.EDU) \\ ${ }^{3}$ Department of Geography, University of Cambridge, Downing Place, Cambridge CB2 3EN, UK \\ (Current address: Department of Earth Sciences, Brock University, St. Catharines, Ontario L2S 3AI, Canada \\ ${ }^{4}$ Museum of Natural History, Burgring 7, 1010, Vienna, Austria
}

\begin{abstract}
Marine organic-walled dinoflagellate cysts have been studied from the Early and Middle Miocene of the Central Paratethys in Austria (Vienna and eastern Alpine Foreland basins) and Hungary (Pannonian Basin), and compared with assemblages of similar age from the Atlantic Ocean and Mediterranean Sea. The presence of a diverse flora of 71 taxa, including such biostratigraphical markers as Apteodinium spiridoides, Cerebrocysta poulsenii, Cordosphaeridium cantharellus, Cribroperidinium tenuitabulatum, Exochosphaeridium insigne, Glaphyrocysta reticulosa s.1., Habibacysta tectata, Labyrinthodinium truncatum subsp. truncatum, Palaeocystodinium miocaenicum, and Unipontidinium aquaeductus, has allowed the establishment of five biozones that characterize the Ottnangian, Badenian and Sarmatian local stages (collectively equivalent to the mid-Burdigalian, upper Langhian and Serravallian stages). This is the first study to demonstrate the applicability of dinoflagellate cysts for detailed stratigraphic correlation and palaeoenvironmental interpretation in the Early and Middle Miocene of the Central Paratethys area. J. Micropalaeontol. 25(2): 113-139, November 2006.
\end{abstract}

KEYWORDS: dinoflagellate cysts, palaeoenvironments, Miocene, Paratethys

\section{INTRODUCTION}

Early and Middle Miocene dinoflagellate cyst (dinocyst) assemblages from the Atlantic Ocean, northern Europe and the Mediterranean region have been documented extensively (e.g. for the Mediterranean - Powell, 1986a, b; Biffi \& Manum, 1988; El Beialy, 1988; Brinkhuis et al., 1992; Zevenboom et al., 1994; Zevenboom, 1995, 1996; Wilpshaar et al., 1996; Montanari et al., 1997; Londeix \& Jan du Chêne, 1998; Torricelli \& Biffi, 2001; El Beialy \& Ali, 2002; for northern Europe - Piasecki, 1980; Rusbült \& Strauss, 1992; Strauss et al., 2001; Dybkjær \& Rasmussen, 2000; Dybkjær, 2004; Schiøler, 2005; for the North Atlantic-Head et al., 1989a, b; Manum et al., 1989; de Verteuil, 1996, 1997; de Verteuil \& Norris, 1996). In contrast, assemblages of this age from the Paratethys Sea are known only from a few early studies (Baltes, 1967, 1969; Hochuli, 1978), although they are better known for the Late Miocene (Sütó-Szentai, 1994, 1995, 2002, 2003)

The present study is the first detailed dinocyst biostratigraphy of Early and Middle Miocene deposits from the Paratethys region; it examines dinocysts from three independently dated Parathethyan sections in Central Europe (Figs 1, 2). Two are outcrop sections in Austria: the Strass-Eberschwang section of Ottnangian (mid-Burdigalian) age, and the Baden-Sooss section of late Early Badenian (late Langhian) age. The Tengelic-2 borehole, located in Hungary and of Badenian and Sarmatian (Langhian-Serravallian) age, is also analysed herein. A dinocyst zonation comprising five zones is established and compared with dinocyst zonations from the Atlantic Ocean, northern Europe and Mediterranean Sea.

\section{GEOLOGICAL SETTING}

The rise of the Alpine mountain belt led to a partition of the Tethyan Ocean at about the Eocene-Oligocene boundary. This geodynamic process caused the Tethys to disappear as a palaeogeographical and palaeobiogeographical entity, and two distinct palaeogeographical areas evolved during the Neogene - the Mediterranean and the Paratethys seas. This geographical separation also resulted in a biogeographical differentiation and has necessitated the establishment of separate chronostratigraphic scales (Figs 3,4). A complex pattern of changing seaways and land bridges existed between the Paratethys and the Mediterranean as well as with the western Indo-Pacific (e.g. Rögl, 1998).

The current study focuses on three basins within the Paratethys realm, the eastern Alpine Foreland Basin, the Vienna Basin and the Pannonian Basin (Fig. 2). The eastern Alpine Foreland Basin, being part of the Alpine-Carpathian Foredeep, is a W-E-trending trough in front of the prograding nappes of the Alpine orogen. Its easternmost part covers the area between the Alpine mountain chain to the south and the Bohemian Massif to the north and is separated from the Vienna Basin to the east by external thrust sheets of the Alpine-Carpathian system (Fig. 2). Marine deposition lasted throughout the Early and Middle Miocene up to approximately $12 \mathrm{Ma}$, when uplift caused the sea to retreat. The Vienna Basin is surrounded by the Eastern Alps, the West Carpathians and the western part of the Pannonian Basin, and represents one of the best-studied pullapart basins in the world (Royden, 1985; Wessely, 1988). The adjacent, much larger, Pannonian Basin is of back-arc type and formed during the Middle Miocene. It is encircled by the Alps to 


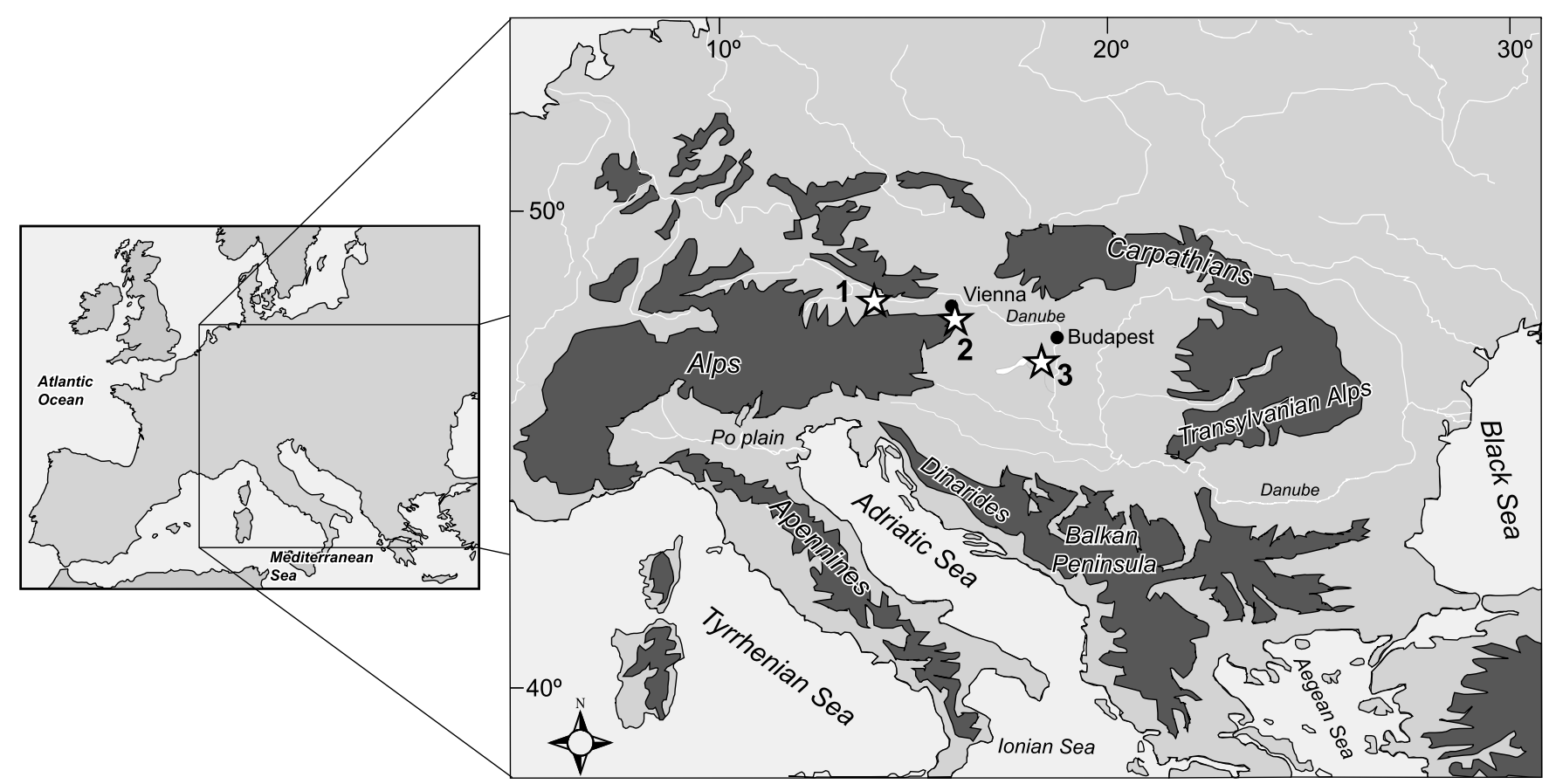

Fig. 1. Location of the examined sections within the Central Paratethys, as surrounded by the Alps, Carpathians and Dinarides. 1, Strass-Eberschwang exposure, Vienna Basin, Austria; 2, Baden-Sooss exposure, Vienna Basin, Austria; 3, Tengelic-2 borehole, Central Paratethys, Hungary. Dark grey shading indicates high relief.

the west, the Carpathians to the north and east and the Dinarides to the south (Royden \& Horváth, 1988; Meulenkamp \& Sissingh, 2003) (Fig. 2).

These basins experienced a long-term trend of decreasing marine influence during the Neogene (Rögl, 1998; Meulenkamp \& Sissingh, 2003). Nevertheless, during the Early and Middle Miocene, broad connections existed with the Mediterranean Sea that enabled a free faunal exchange between those two regions (Harzhauser et al., 2003; Fig. 2). Consequently, marine organ- isms are similar in both the Mediterranean Basin and Pannonian and Vienna Basins at this time. The first impairment of marine connections is evident in the Late Badenian (early Serravallian) when dysaerobic bottom conditions and a stratified water column characterized the Paratethyan realm (Kovac et al., 2004). With the onset of the Sarmatian, marine connections to the Mediterranean ceased almost completely, this being reflected by the development of a highly endemic molluscan fauna (Harzhauser \& Piller, 2004a). Finally, at the Sarmatian-

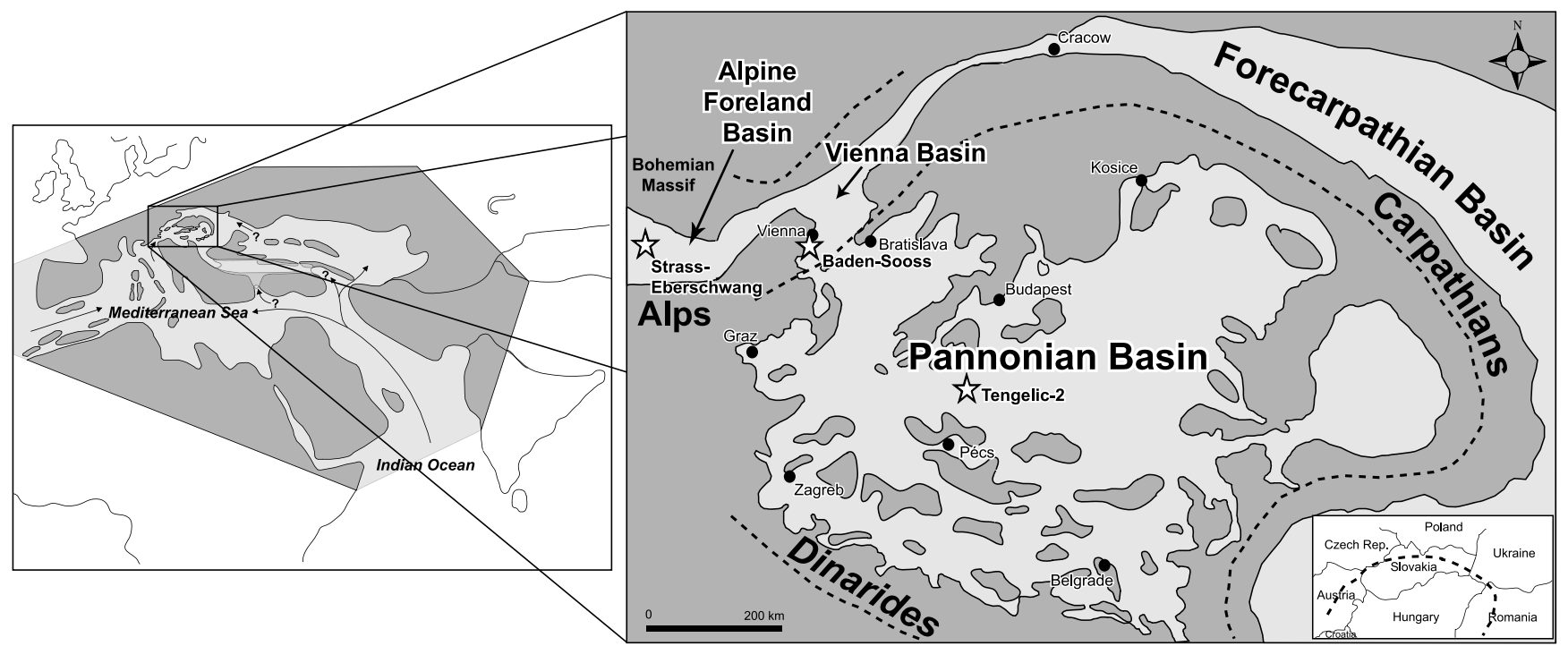

Fig. 2. Palaeogeography of the Pannonian Basin and surrounding basins during the early Middle Miocene (Langhian Stage); modified from Hamor (1995) and Rögl (1998). Location of examined sites is indicated by stars. The dashed line indicates axes of the main structural highs. Light grey shading indicates marine conditions. The Vienna and Pannonian basins had broad connections with the Mediterranean Sea and Indian Ocean at this time. 


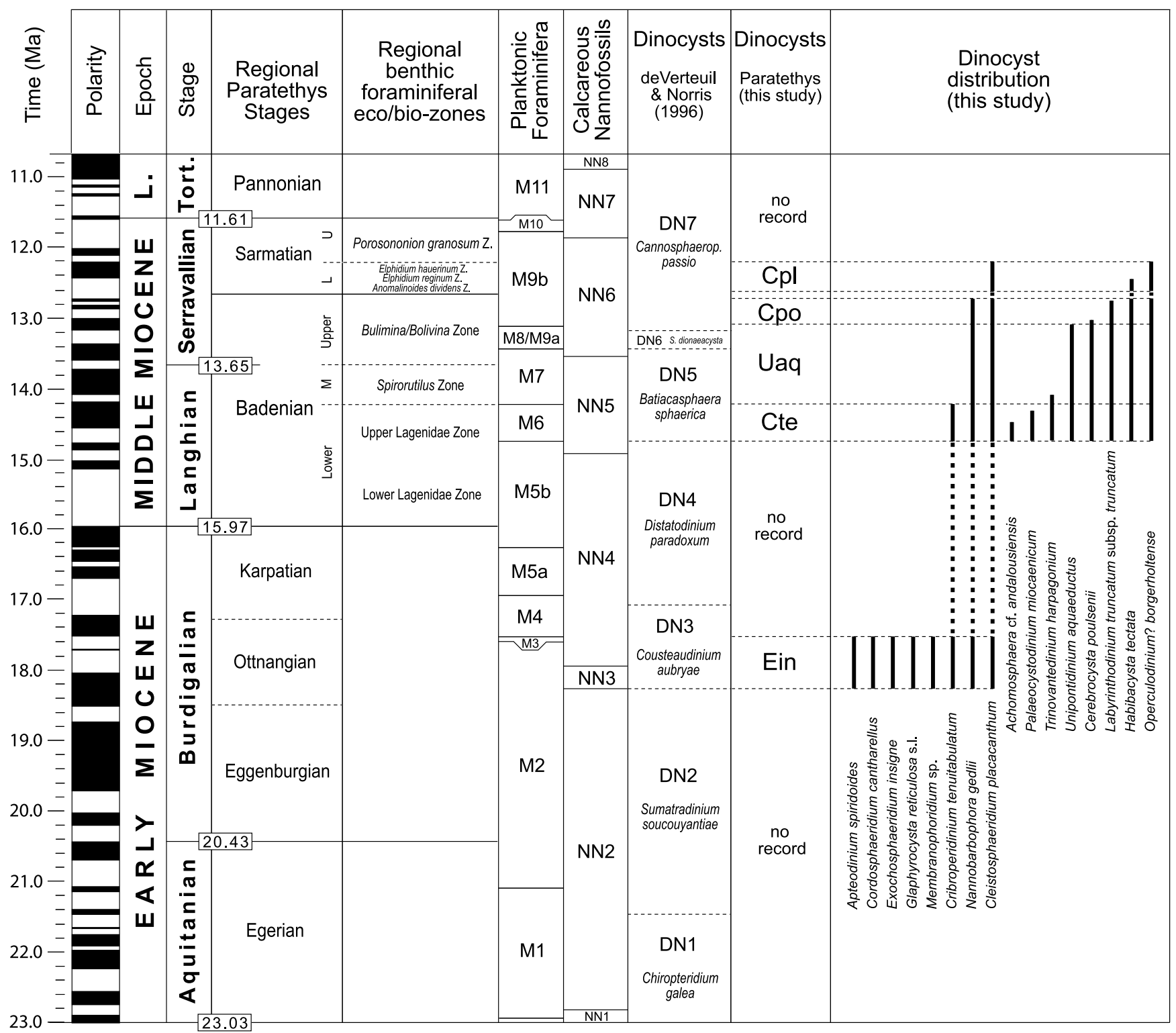

Fig. 3. Chronostratigraphic framework used in this study. Based on Gradstein et al. (2004) and Steininger et al. (1990, 1996), showing the dinocyst zones of de Verteuil \& Norris (1996) and temporal distribution of stratigraphically indicative species used in this study. The three standard stages are distinctly characterized by dinocysts, illustrating their biostratigraphic utility for the Central Paratethys.

Pannonian boundary (Serravallian-Tortonian boundary), the Central Paratethys became entirely restricted and the brackish Lake Pannon was established.

\section{LOCALITIES}

\section{Strass-Eberschwang, Austria}

This section $\left(48^{\circ} 08^{\prime} 10.2^{\prime \prime} \mathrm{N}, 13^{\circ} 32^{\prime} 18.6^{\prime \prime} \mathrm{E}\right)$, from the eastern Alpine foredeep of northern Austria, displays up to $30 \mathrm{~m}$ of clayey silt belonging to the Middle Ottnangian (Burdigalian) Ried Beds of the Innviertel Group (Fig. 5). The section is characterized by thin-bedded pelites with lenticular bedding (Rupp et al., 1996) and strong bioturbation by echinoderms. These pelites coarsen upwards, becoming increasingly sandy towards the top, suggesting a shallowing-upward trend during the Ottnangian. The abundance of the benthic foraminiferid Ammonia in the sediments is reflected in the informal lithological name Rotalia-beds of the older literature (Faupl \& Roetzel, 1987). The palaeoenvironment is considered normal marine judging from the foraminiferal and molluscan fauna, although with the dominance of Ammonia reflecting shallow conditions (F. Rögl, pers. comm.). Correlation with the regional Ottnangian Stage is based on the co-occurrence of Globigerina praebulloides and G. ottnangiensis among the planktonic fauna and Stilostomella ottnangiensis, Bolivina concinna and B. scitula among the benthos. The stratigraphic position of the Ried Beds within the Innviertel Group, overlying Lower Ottnangian siliciclastics and overlain by the Upper Ottnangian brackish Rzehakia beds, allows correlation with the Middle Ottnangian (Faupl \& Roetzel, 1987). According to Kovac et al. (2004), the Middle 


\begin{tabular}{|c|c|c|c|}
\hline SECTION & STAGE & $\begin{array}{c}\text { REGIONAL } \\
\text { BENTHIC ZONES }\end{array}$ & $\begin{array}{l}\text { CALCAREOUS } \\
\text { NANNOPLANKTON }\end{array}$ \\
\hline $\begin{array}{l}\text { Tengelic-2 } \\
(723-702 \mathrm{~m})\end{array}$ & $\begin{array}{l}\text { Lower } \\
\text { Sarmatian }\end{array}$ & $\begin{array}{c}\text { Elphidium reginum } \\
\text { Anomalinoides dividens } \\
\text { interpreted from Korecz-Laky (1982) }\end{array}$ & \\
\hline $\begin{array}{l}\text { Tengelic-2 } \\
(802-723 \mathrm{~m})\end{array}$ & $\begin{array}{l}\text { Upper } \\
\text { Badenian }\end{array}$ & $\begin{array}{l}\text { Bulimina-Bolivina } \\
\text { interpreted from Korecz-Laky (1982) }\end{array}$ & $\begin{array}{c}\text { NN6 } \\
\text { Nagymarosy (1982) }\end{array}$ \\
\hline $\begin{array}{l}\text { Tengelic-2 } \\
(823-802 \mathrm{~m})\end{array}$ & $\begin{array}{c}\text { Middle } \\
\text { Badenian }\end{array}$ & $\begin{array}{l}\text { Spirorutilus } \\
\text { interpreted from Korecz-Laky (1982) }\end{array}$ & $\begin{array}{c}\text { NN5 } \\
\text { Nagymarosy (1982) }\end{array}$ \\
\hline $\begin{array}{c}\text { Tengelic-2 } \\
(847-823 \mathrm{~m})\end{array}$ & $\begin{array}{l}\text { Lower } \\
\text { Badenian }\end{array}$ & $\begin{array}{l}\text { Upper Lagenidae } \\
\text { Korecz-Laky (1982) }\end{array}$ & $\begin{array}{c}\text { NN5 } \\
\text { Nagymarosy (1982) }\end{array}$ \\
\hline Baden-Sooss & $\begin{array}{l}\text { Lower } \\
\text { Badenian }\end{array}$ & $\begin{array}{c}\text { Upper Lagenidae } \\
\text { Papp \& Steininger (1978) }\end{array}$ & $\begin{array}{c}\text { NN5 } \\
\text { interpreted from } \\
\text { Fuchs \& Stradner (1977) }\end{array}$ \\
\hline $\begin{array}{c}\text { Strass- } \\
\text { Eberschwang }\end{array}$ & $\begin{array}{c}\text { Middle } \\
\text { Ottnangian }\end{array}$ & & $\begin{array}{c}\text { NN3 } \\
\text { indirect dating based on correlation } \\
\text { with equivalents in Vienna Basin }\end{array}$ \\
\hline
\end{tabular}

Fig. 4. Foraminiferal and calcareous nannofossil zonations for the studied intervals. Note that the boundary between the Spirorutilus and the Bulimina-Bolivia zones in the Tengelic-2 borehole at $802 \mathrm{~m}$ is inferential only, due to the lack of significant index fossils. The correlation with the Late Badenian is therefore based mainly on the calcareous nannofossil data of Nagymarosy (1982). Data from Fuchs \& Stradner (1977), Papp \& Steininger (1978), Korecz-Laky (1982) and Nagymarosy (1982).

Ottnangian is correlated with the calcareous nannofossil zone NN3 of Martini \& Worsley (1970) and with the planktonic foraminiferal zone M3 of Berggren et al. (1995).

Rupp et al. (1996) interpreted the depositional environment as deep sublittoral marine which was prone to tidal influence based on the benthic foraminifera (Faupl \& Roetzel, 1987). These meso- and macrotidally controlled conditions extended from the Austrian part of the Alpine foreland basin westward into the Swiss and French Molasse during the late Early Miocene (e.g. Allen \& Homewood, 1984; Lesueur et al., 1990). This hydrodynamic regime resulted from an effective but shortlived connection of the Paratethys with the western Mediterranean Sea via the Rhône valley (Rögl, 1998) and also from a connection with the Eastern Mediterranean (Martel et al., 1994).

Pollen analyses indicate a subtropical climate judging from the presence of several megathermic elements including Avicennia (developing an impoverished mangrove along the coastal areas), Acacia, Acanthaceae, etc., and the mega-mesothermic elements Engelhardia, Myrica, Sapotaceae, Taxodium type, etc. (Jiménez-Moreno, 2005).

The Ottnangian pelites are discordantly overlain by fluviallacustrine deposits of Late Pannonian age known as the 'coalbearing freshwater beds' (Rupp et al., 1996).

\section{Baden-Sooss, Austria}

The Wienerberger clay pit $\left(47^{\circ} 59^{\prime} 21.3^{\prime \prime} \mathrm{N}, 16^{\circ} 13^{\prime} 46.9^{\prime \prime} \mathrm{E}\right)$ at Baden-Sooss in the Vienna Basin, Lower Austria, contains the stratotype of the Badenian Stage (Papp \& Steininger, 1978; Fig. 5). The calcareous nannofossils indicate zone NN5 of Martini \& Worsley (1970) with a diverse nannoflora (Fuchs \& Stradner, 1977; Papp \& Steininger, 1978).

The Baden-Sooss section is also assigned to the Upper Lagenidae Zone (Papp \& Steininger, 1978) based on an ecostratigraphic foraminiferal zonation for the region. Furthermore, the lowest occurrence of Orbulina suturalis allows a correlation with the planktonic foraminiferal zone M6 of Berggren et al. (1995). Hence, the Baden-Sooss section can be correlated with the upper Langhian.

The homogeneous clay contains scattered molluscs, such as the naticid Euspira helicina, the pectinid Costellamussiopecten cristatum, various turrid gastropods, and the scaphopods Fissidentalium badense and Antalis bouei. This autochthonous assemblage indicates a medium-deep sublittoral soft-bottomed environment between approximately $50 \mathrm{~m}$ and $150 \mathrm{~m}$ water depth inhabited by infaunal predators. Pteropods point to open-marine connections.

Pollen analyses indicate a subtropical climate for the Badenian in this area, as high percentages of megathermic elements (Euphorbiaceae, Mussaenda type, Rubiaceae, etc.) and megamesothermic elements (Taxodium type, Engelhardia, Myrica, etc.) have been recorded (Jiménez-Moreno, 2005).

\section{Tengelic-2 borehole, Hungary}

The $1183 \mathrm{~m}$ deep Tengelic-2 borehole $\left(46.5333328^{\circ} \mathrm{N}\right.$, $\left.18.7166672^{\circ} \mathrm{E}\right)$ is located in the Pannonian Basin in southern Hungary, close to the Mecsek Mountains and near the village of Pécs (Fig. 2). Marine sediments of Badenian and Sarmatian age (collectively Langhian and Serravallian) are present in this core. Age control is based on calcareous nannofossils (Nagymarosy, 1982), molluscs (Bohn-Havas, 1982) and planktonic foraminifera (Korecz-Laky, 1982) (Fig. 5).

The Karpatian is characterized mainly by terrigenous effusive volcanites, known as the Tar Dacite-Tuff Formation (1174.4 $853.3 \mathrm{~m}$ ). The volcanic sediments have been dated by K/Ar radiometry, with the youngest sample (at $872 \mathrm{~m}$ core depth) yielding an age of $16 \pm 0.7 \mathrm{Ma}$ (Hálmai et al., 1982). Intercalations of layers of lacustrine to brackish sediment reflect the progressive transition from continental to brackish conditions.

The Karpatian deposits are discordantly overlain by the Badenian Clay Formation (853.3-823.4 m), starting with a layer of terrestrial gravel. The overlying succession of grey siltstones, dark argillaceous marls and grey siltstones are dated as late Early Badenian and assigned to the Upper Lagenidae Zone based on a predominance of genera and species of the family Lagenidae (according to the biozonation of Grill, 1941, 1943) co-occurring with Orbulina universa and $O$. bilobata (Korecz-Laky, 1982). Following Rögl et al. (2002), this typical Paratethyan assemblage can be correlated with the planktonic foraminiferal zone M6 of Berggren et al. (1995). Therefore, marine deposits of the Lower Lagenidae Zone, representing the early Early Badenian and comprising equivalents of the planktonic foraminiferal zone M5b of Berggren et al. (1995) and the nannoplankton zone NN4 of Martini \& Worsley (1970), are completely missing. Indeed, calcareous nannofossils for this interval allow assignment to zone NN5 (Nagymarosy, 1982). At that time, the area was already occupied by the shallow Paratethys Sea. This part of the borehole can therefore be dated as late Langhian.

A change from light siltstones to dark, organic-rich argillaceous marls at $823.4 \mathrm{~m}$ marks the onset of Middle and Late Badenian sedimentation as represented by the Szilágy Formation (823.4-723.1 m). This lithological change is accompanied by a biostratigraphic change, suggesting a brief hiatus. The benthic foraminiferal assemblage (Korecz-Laky, 1982) allows 


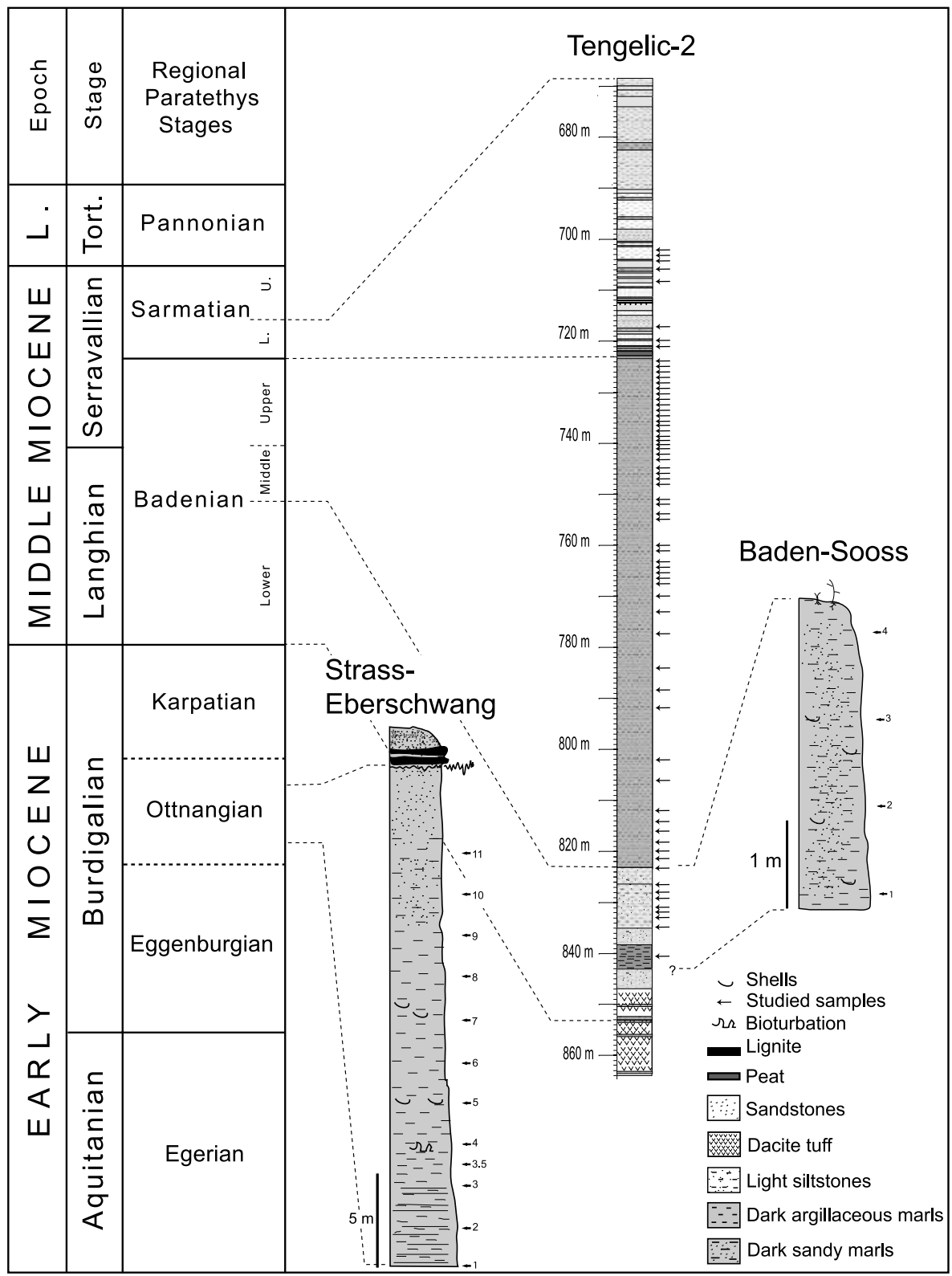

Fig. 5. Lithology of the studied sections showing the position of samples analysed in the present study. The age assignment for the StrassEberschwang section is based on molluscs and foraminifera (Rupp et al., 1996), as is the Baden-Sooss section (Papp \& Steininger, 1978). The age assignment for the Tengelic-2 core is based on planktonic foraminifera and nannofossils (Korecz-Laky, 1982; Nagymarosy, 1982).

assignment to the Middle Badenian Spirorutilus Zone up to approximately $802 \mathrm{~m}$ based on cross-correlation with the nannofossil data and, above this, to the Upper Badenian BuliminaBolivina Zone, based on the regional eco-zonation of Grill (1941, 1943). It should be noted that assignment to the BuliminaBolivina Zone is considered most likely, although such index fossils as Velapertina and Pappina neudorfensis are missing. The calcareous nannofossil flora indicates zone NN5 up to $802 \mathrm{~m}$ (Nagymarosy, 1982), allowing correlation with the uppermost Langhian and lowermost Serravallian. The upper part of the Szilágy Formation from $802-723 \mathrm{~m}$ is dated as NN6 (Nagymarosy, 1982) based on the absence of Sphenolithus heteromorphus, pointing to a Serravallian age (Fornaciari et al., 1996).
According to Kókay (1996), the uppermost part of the Badenian was eroded during an important regression that represents a type 1 third-order sequence boundary of Haq et al. (1988). The Sarmatian therefore lies on an unconformity at $723 \mathrm{~m}$. It comprises sands, limestones, light-grey clays and lignites of an unnamed formation, reflecting shallower-marine and freshwater-paludal conditions that developed in the now isolated inland sea with aberrant water chemistry (Hámor, 1995; Rögl, 1998; Harzhauser \& Piller, 2004a).

Within the Central Paratethys, the Badenian-Sarmatian boundary is characterized by an important biotic change. The foraminiferal fauna becomes characterized by a low diversity but high abundance of individuals dominated by the genera 


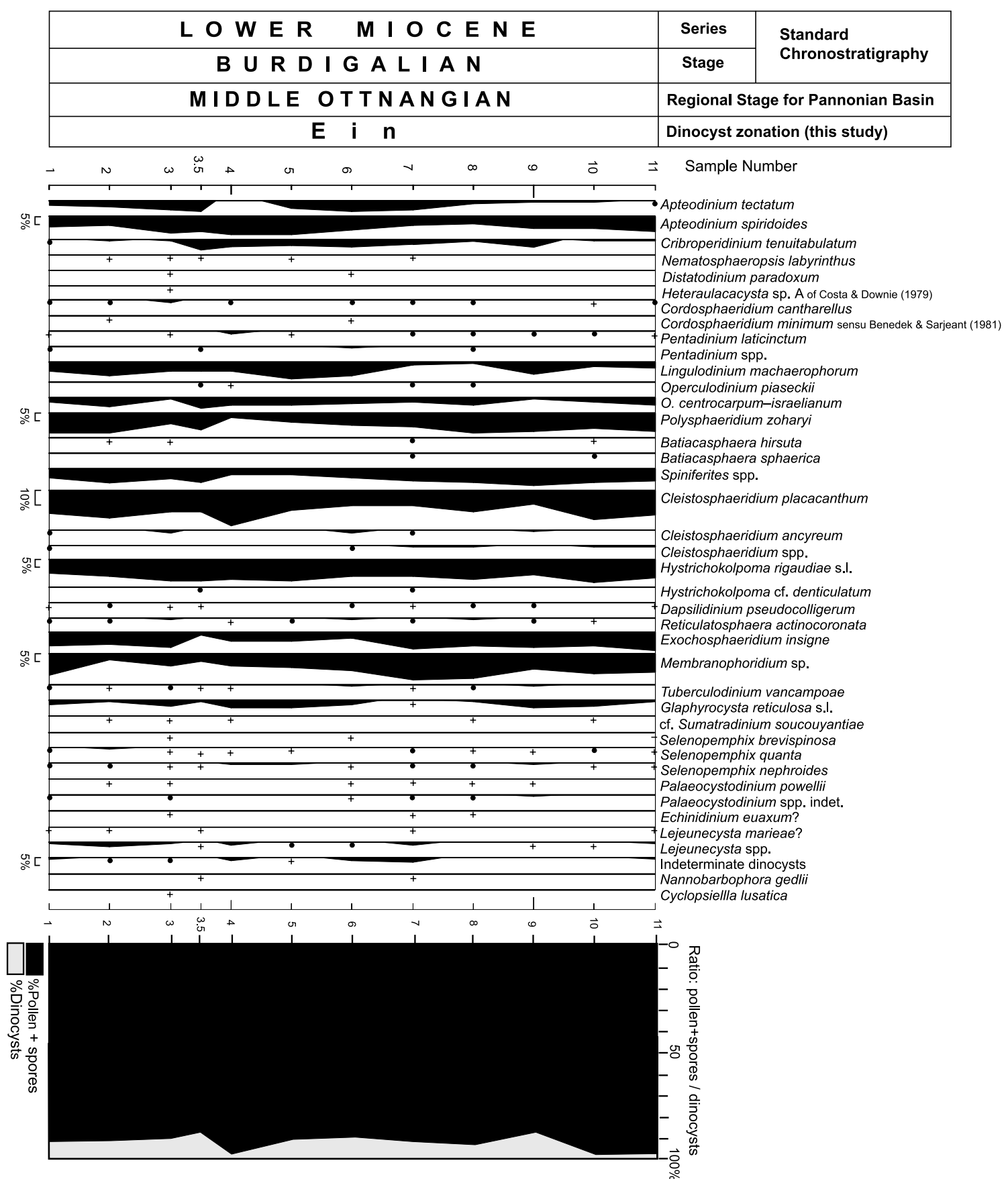

Fig. 6. Dinocyst distribution in the Strass-Eberschwang section, eastern Alpine foredeep, Austria. Sample positions are shown in Figure 5. A solid dot indicates taxa recorded in the counts with frequencies below $1 \%$. A cross $(+)$ indicates rare occurrences of taxa recorded outside of the counts.

Elphidium, Porosononion and Rotalia (Rögl, 1998). Changes in the calcareous nannofossil flora resulted from a shift in water chemistry, rendering a direct comparison with Mediterranean zonations difficult. Correspondingly, in the Tengelic-2 borehole the nannoplankton and foraminiferal diversities drop considerably with the onset of the Sarmatian (Nagymarosy, 1982; Korecz-Laky, 1982). The Sarmatian nannofossil floras comprise long-ranging euryhaline species including Reticulofenestra pseudoumbilica, Coronosphaera mediterranea, Braarudosphaera bigelowi and Cyclococcolithus macintyrei. Aside from the endemic foraminiferal assemblage and endemic mollusc species such as Venerupis tricuspis and Chartocardium carasi (syn. C. gleichenbergense), the abundance of Cyclococcolithus macintyrei in these sediments locally (within the Paratethys area) indicates a Sarmatian age (Nagymarosy, 1982).

Pollen results from this borehole clearly reflect climate evolution since the late Burdigalian. The world-wide Miocene Climatic Optimum of the latest Burdigalian-early Langhian (from 


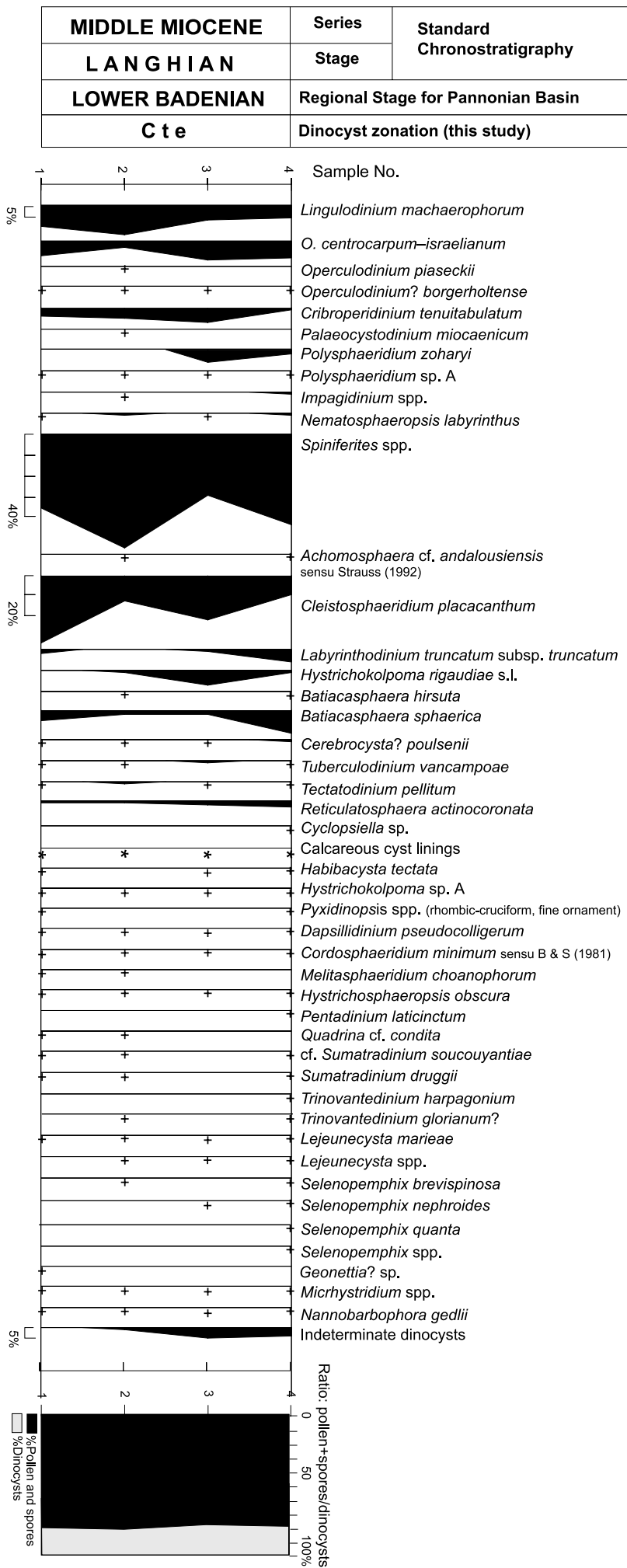

Fig. 7. Dinocyst distribution in the Baden-Sooss section, Vienna Basin, Austria. Sample positions are shown in Figure 5. A solid dot indicates taxa recorded in the counts with frequencies below $1 \%$. A cross $(+)$ indicates rare occurrences of taxa recorded outside of the counts. Calcareous cyst linings (see Appendix A) were not enumerated owing to preservational difficulties, but their presence is indicated by an asterisk $(*)$.
$863 \mathrm{~m}$ to $825 \mathrm{~m}$, equivalent to the Karpatian-Early Badenian local stages), as well as a climatic cooling (the 'Monterey cooling event') which is related to the development of the East Antarctic Ice Sheet and occurred during the late Langhian and Serravallian starting at 14.2 Ma (Shevenell et al., 2004) (from $825 \mathrm{~m}$ upwards, Middle and Late Badenian-Sarmatian local stages), are well expressed by the pollen flora along the borehole (Jiménez-Moreno et al., 2005).

\section{MATERIAL AND METHODS}

A total of 82 samples, comprising 12 from Strass-Eberschwang, 4 from Baden-Sooss, and 66 core samples from the Tengelic-2 borehole, were studied for dinocysts. Samples range from Ottnangian to Early Sarmatian (mid-Burdigalian to Serravallian) in age. Pollen grains were also studied (Jiménez-Moreno, 2005; Jiménez-Moreno et al., 2005). Between $20 \mathrm{~g}$ and $30 \mathrm{~g}$ were processed for palynological analysis, using cold $\mathrm{HCl}(35 \%)$ and $\mathrm{HF}(70 \%)$, followed by separation of the organic residue by means of $\mathrm{ZnCl}$ (density >2.0). The residue was sieved at $10 \mu \mathrm{m}$ using a nylon mesh, mixed with glycerine, and mounted on microscope slides. At least 200 dinocysts were counted (by G.J.-M.) for each sample analysed and slides were further searched (by M.J.H.) for rare taxa. Additional residue of selected samples from all sites was sieved at $20 \mu \mathrm{m}$ and mounted in glycerine jelly. These slides were used for taxonomic verification, the searching of rare taxa and photography. Percentage occurrences and occurrences of rare taxa are shown on Figures 6-8. Important species are illustrated on Plates 1-9. A sample at $777.0 \mathrm{~m}$ from the Tengelic-2 core was examined under SEM, and illustrations are shown on Plate 9. Dinocyst nomenclature generally follows that of Fensome \& Williams (2004) which comprehensively cites the taxonomic literature. A list of all taxa encountered in the present study, including full authorial citations, is given online as Table 1 . (Table 1 is available at http://www.geolsoc.org.uk/SUP18252. A hard copy can be obtained from the Geological Society Library.) Comments on selected taxa are given in Appendix A. The time-scale of Gradstein et al. (2004) is used throughout, and ages in the literature based on earlier time-scales are updated accordingly.

\section{PALYNOLOGICAL RESULTS}

Dinocysts and pollen are mostly well preserved in the studied sediments. Pollen and spores clearly dominate the palynomorph assemblages in the three studied sections (Figs 6-8), reflecting the proximity of land to the marine depositional environment. A few samples were found to be barren of palynomorphs. Other samples yielded no dinocysts but were rich in pollen (e.g. continental samples Teng-722 and 721 from the Tengelic-2 borehole), or were rich in dinocysts but had few or no pollen (e.g. samples Teng-702, 703 and 704 of the same borehole). These variations clearly relate to the depositional environment. A total of 68 dinocyst taxa were recorded in the 82 studied samples. In the Tengelic-2 borehole, oscillations in the sporomorph/dinocyst ratio are linked to sea-level changes.

\section{DINOCYST ZONATION}

Changes in the dinocyst assemblages through the studied sections have allowed five local dinocyst zones to be defined for the 


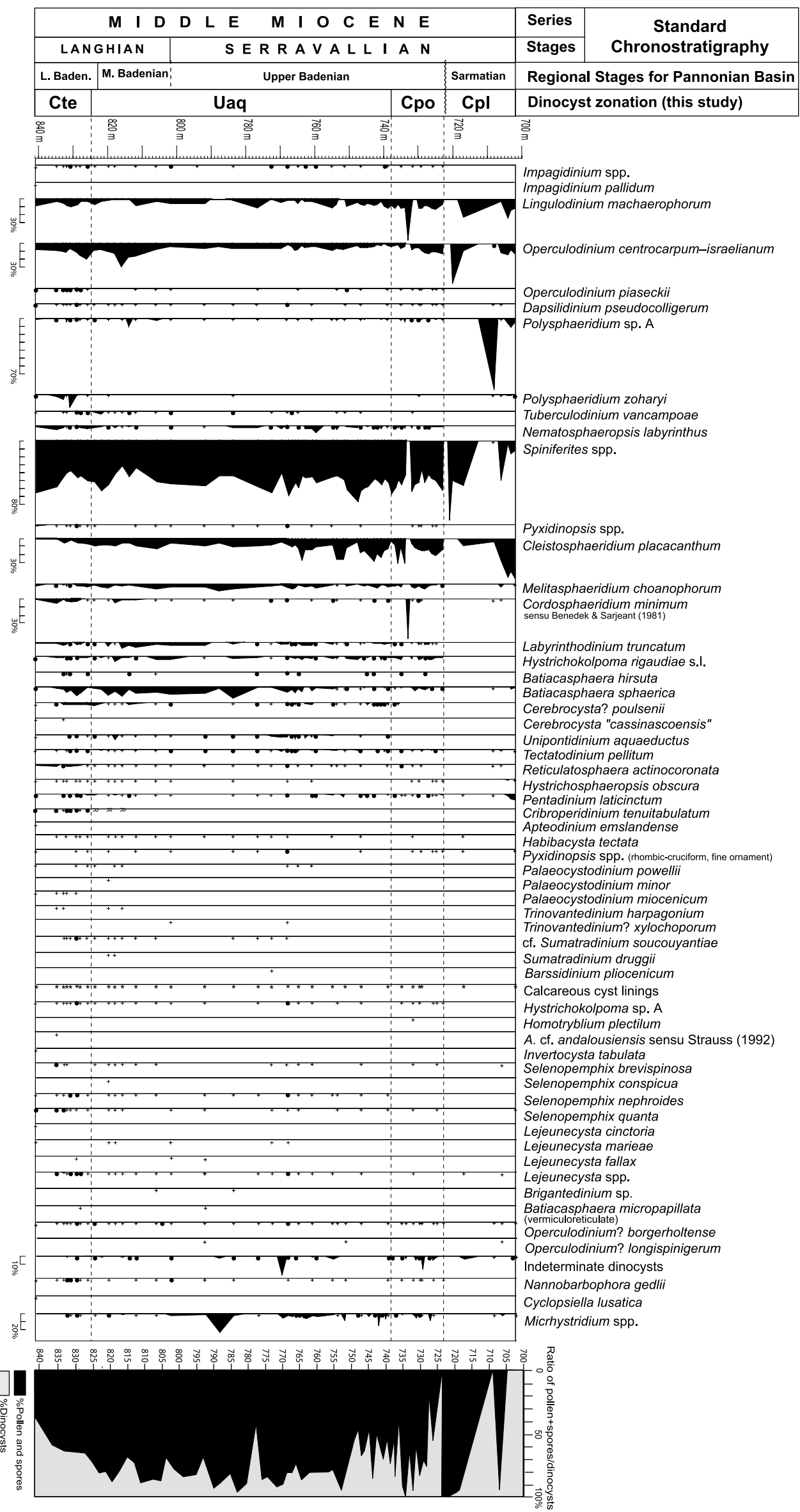



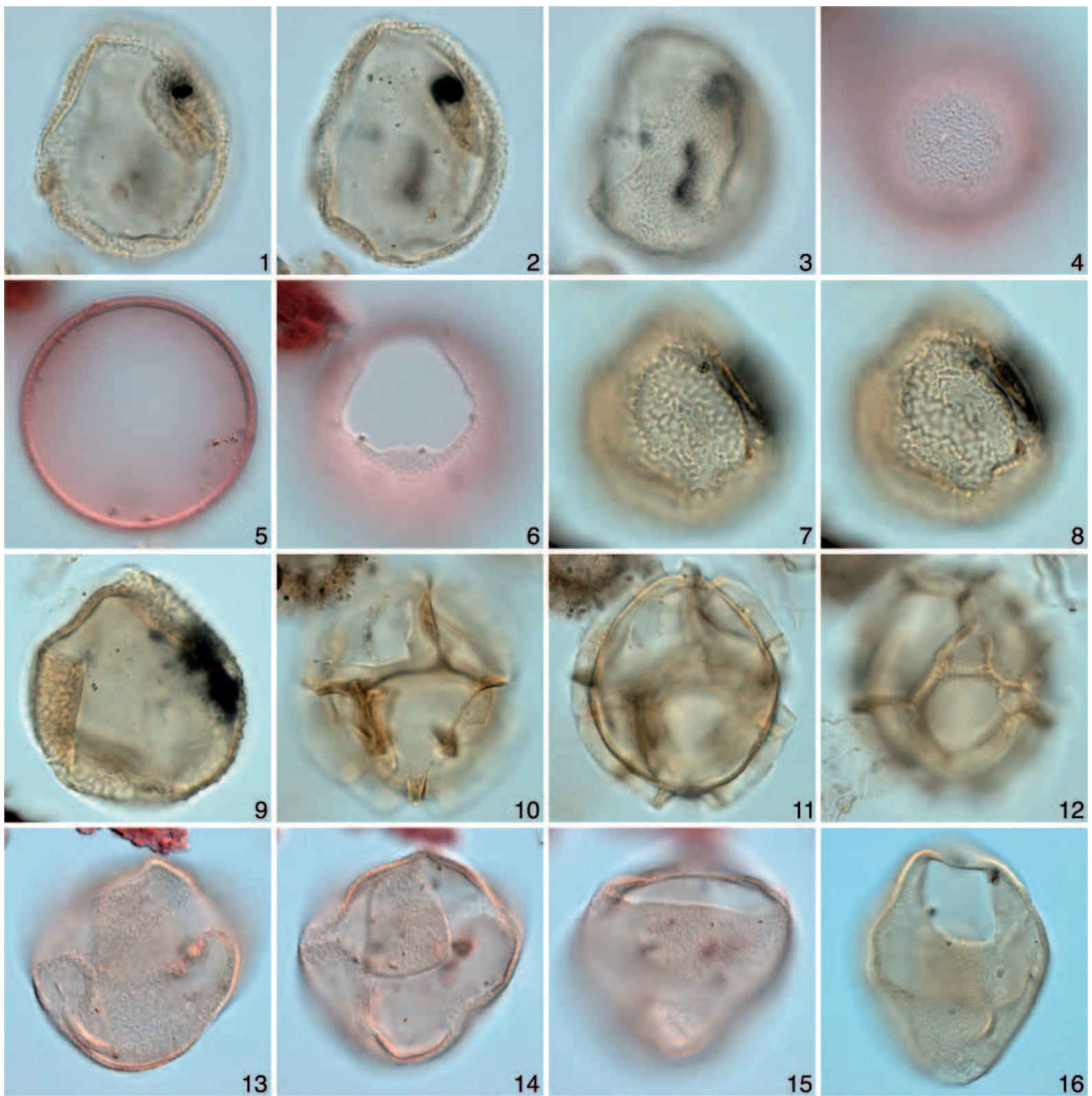

12
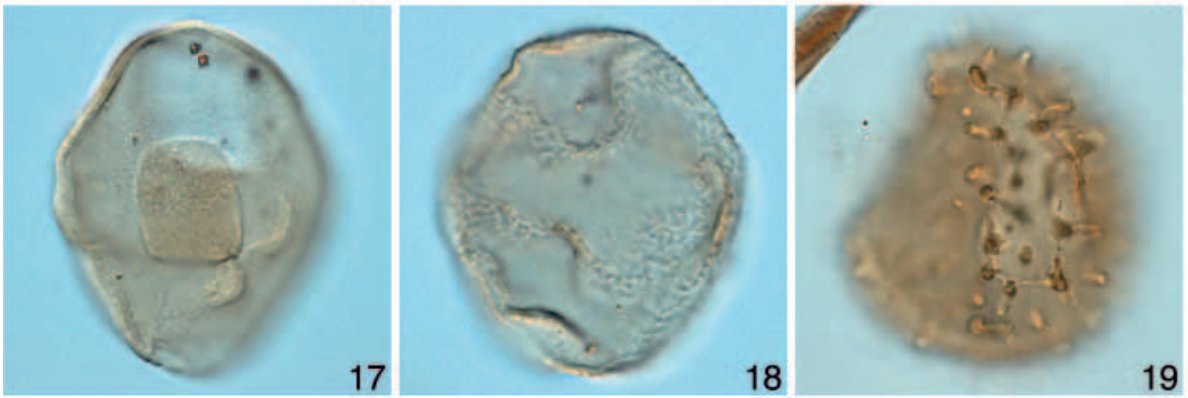

15

Plate 1. For full plate explanation see page 130.

Fig. 8. Dinocyst distribution in the Tengelic-2 borehole, Hungary. Sample positions are shown in Figure 5. A solid dot indicates taxa recorded in the counts with frequencies below $1 \%$. A cross $(+)$ indicates rare occurrences of taxa recorded outside of the counts; and an ' $R$ ' indicates probable reworking. Calcareous cyst linings (see Appendix A) were not enumerated owing to preservational difficulties, but their presence is indicated by an asterisk $(*)$. 

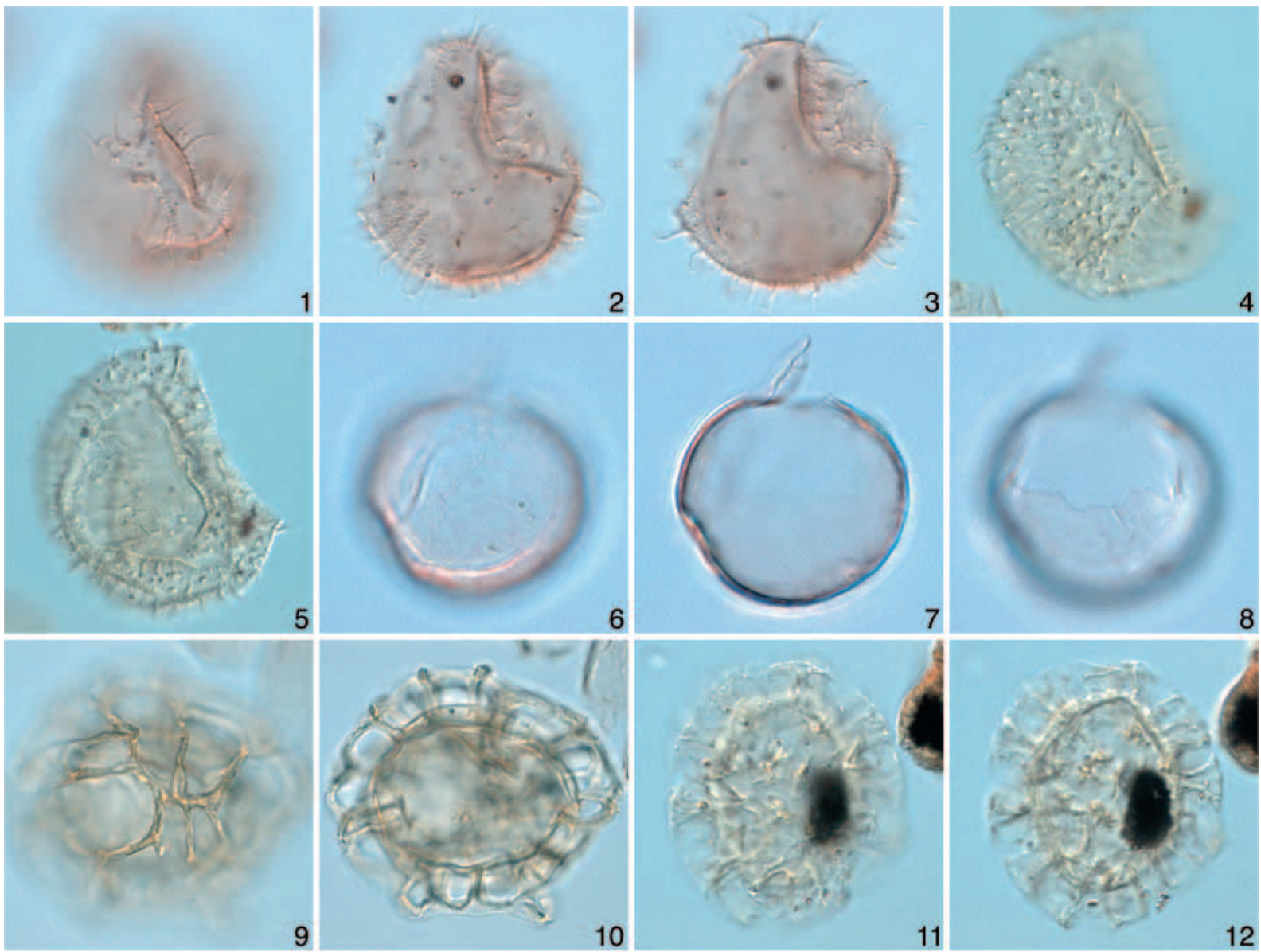

8
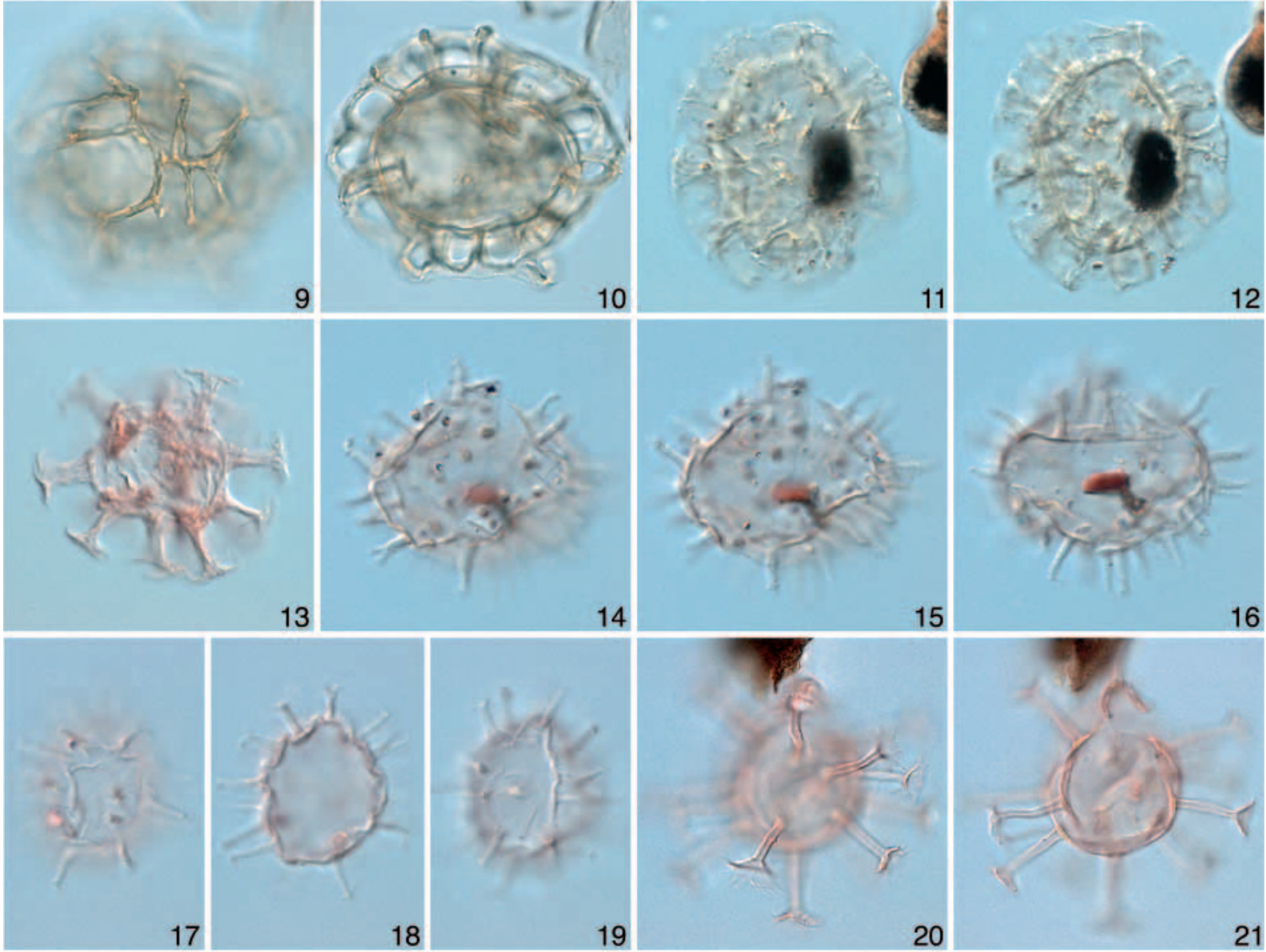

16

Plate 2. For full plate explanation see page 130.

Central Paratethys. Where possible, these local biozones have been calibrated with those more widely recognized biozonations based on nannofossils (Martini \& Worsley, 1970) and foraminifera (Berggren et al., 1995).

\section{Exochosphaeridum insigne Assemblage Biozone (Ein)}

Definition. Interval characterized by the combined presence of Apteodinium spiridoides, Cordosphaeridium cantharellus, Exo- 

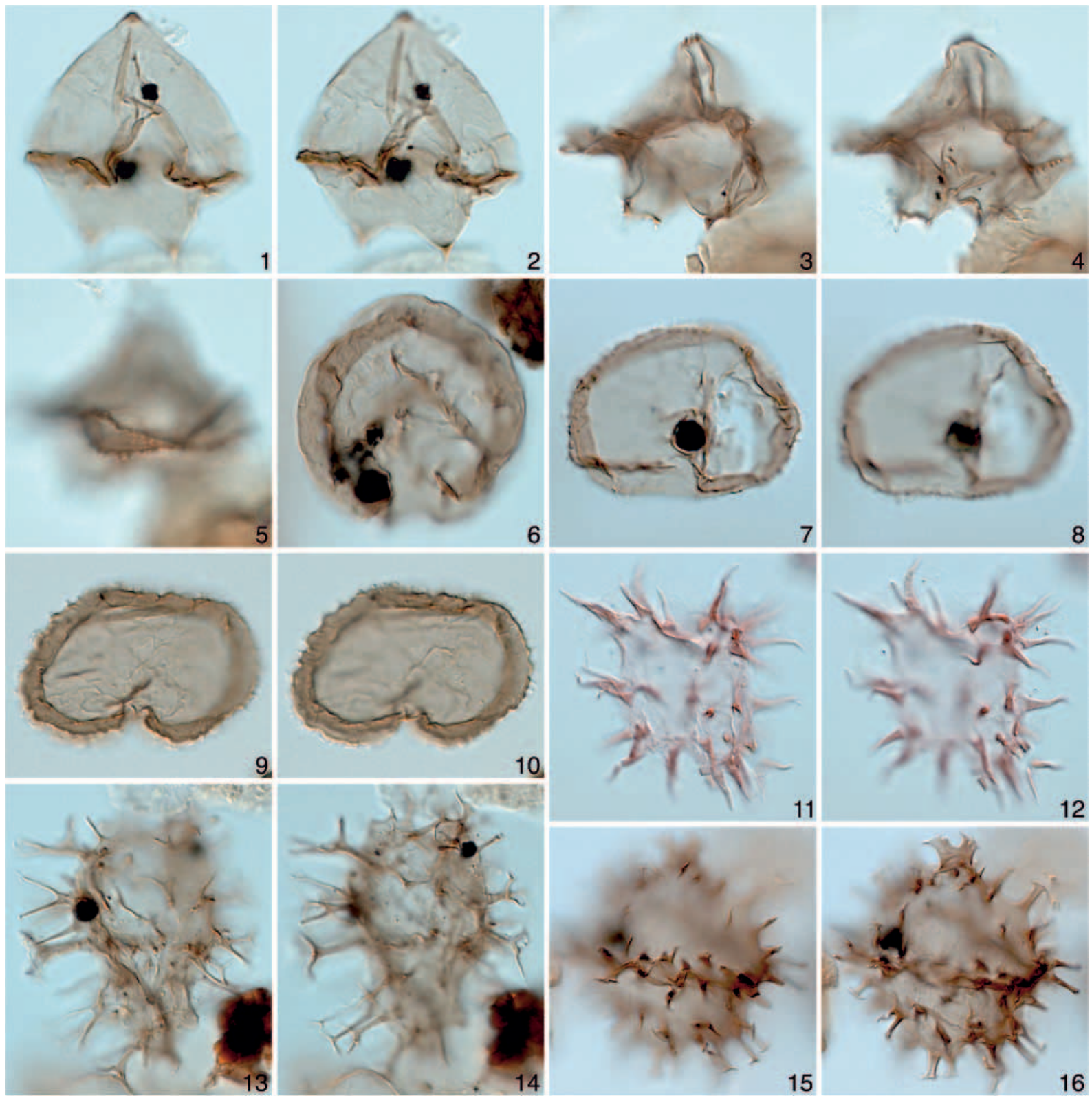

Plate 3. For full plate explanation see page 130.

chosphaeridium insigne, Glaphyrocysta reticulosa sensu lato and Membranophoridium sp.

Other characteristic taxa. Cleistosphaeridium placacanthum, Cribroperidinium tenuitabulatum, Hystrichokolpoma rigaudiae, Lingulodinium machaerophorum, Operculodinium centrocarpumisraelianum, Pentadinium laticinctum, Polysphaeridium zoharyi, Reticulatosphaera actinocoronata and cf. Sumatradinium soucouyantiae.

Reference section. Strass-Eberschwang section, eastern Alpine Foreland Basin, Austria; thickness $23 \mathrm{~m}$, samples 1-11 (12 samples).
Correlation. The Ried Beds are correlated with the middle part of the regional Ottnangian Stage based on their foraminiferal assemblage and lithostratigraphic position (Faupl \& Roetzel, 1987; Rupp et al., 1996). Age-equivalent deposits in the Vienna Basin have been assigned to nannofossil zone NN3 and planktonic foraminiferal zone M3 (mid-Burdigalian) by Kovac et al. (2004).

Age. A typical Burdigalian association (Londeix \& Jan du Chêne, 1998) is represented and includes the biostratigraphic markers Apteodinium spiridoides (P1. 6, figs 1-3), Exochosphaeridium insigne ( $\mathrm{Pl}$. 7, figs 1-3; not reported in the Burdigalian stratotype), and Cordosphaeridium cantharellus (P1. 6, figs 11, 

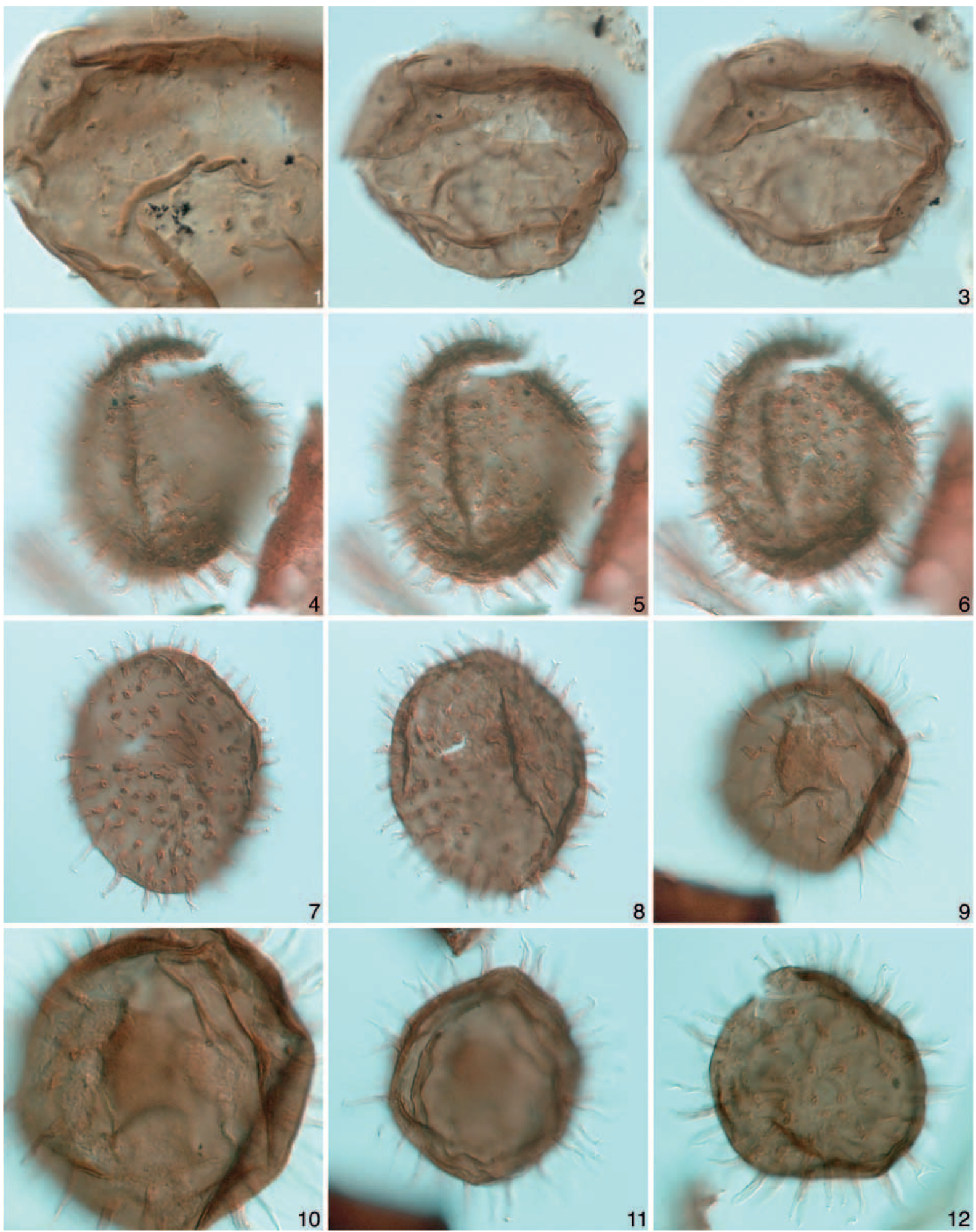

Plate 4. For full plate explanation see page 130.

12). A. spiridoides has a range top within dinocyst zone DN4 (latest Burdigalian and early Langhian) of the eastern USA (de Verteuil \& Norris, 1996). In northwestern Italy it has a sporadic occurrence up to about $17 \mathrm{Ma}$ (late Burdigalian; Zevenboom, 1995). C. cantharellus has a range top of $17.8 \mathrm{Ma}$ in low latitudes (Williams et al., 2004). Exochosphaeridium insigne has a 

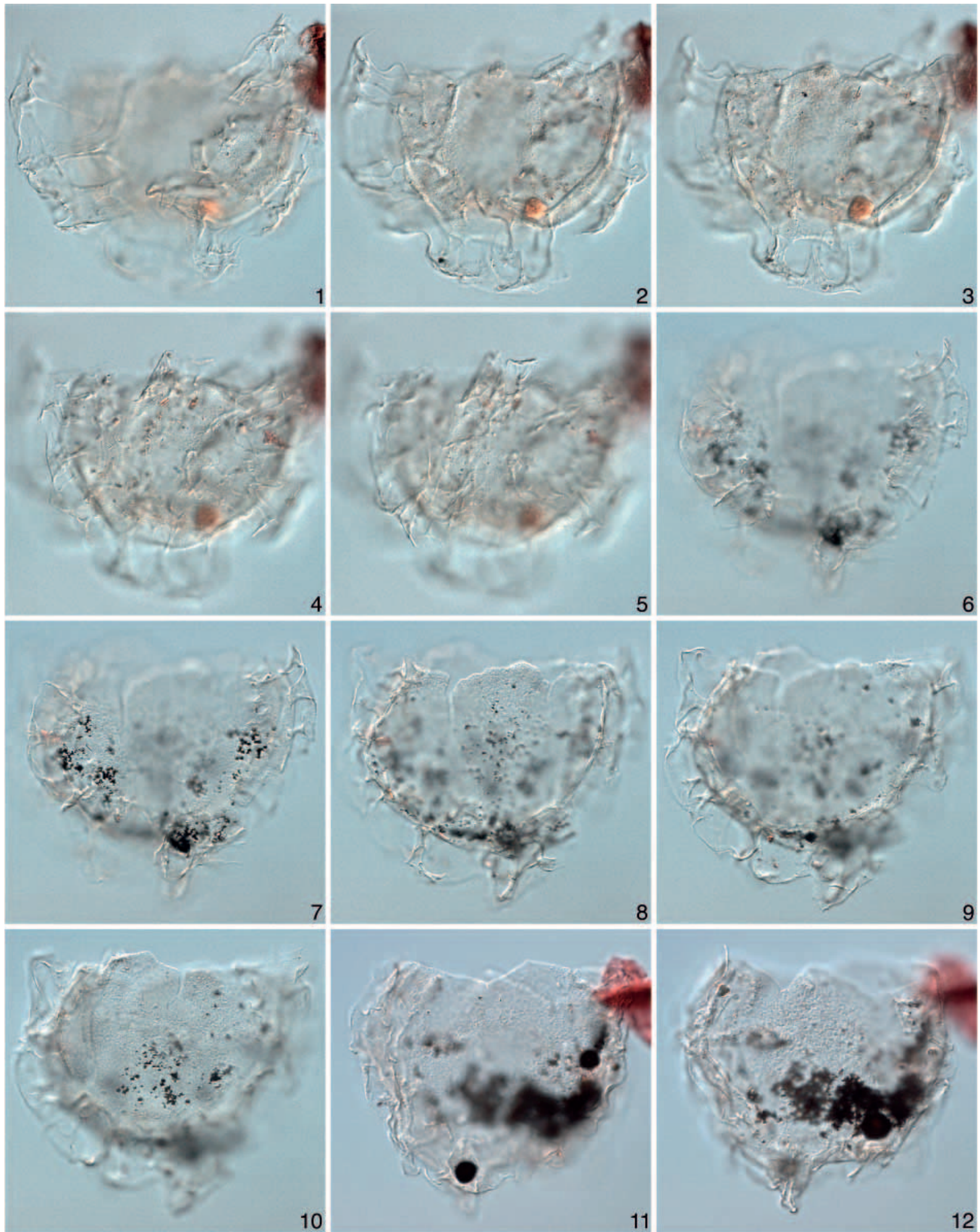

Plate 5. For full plate explanation see page 130. 

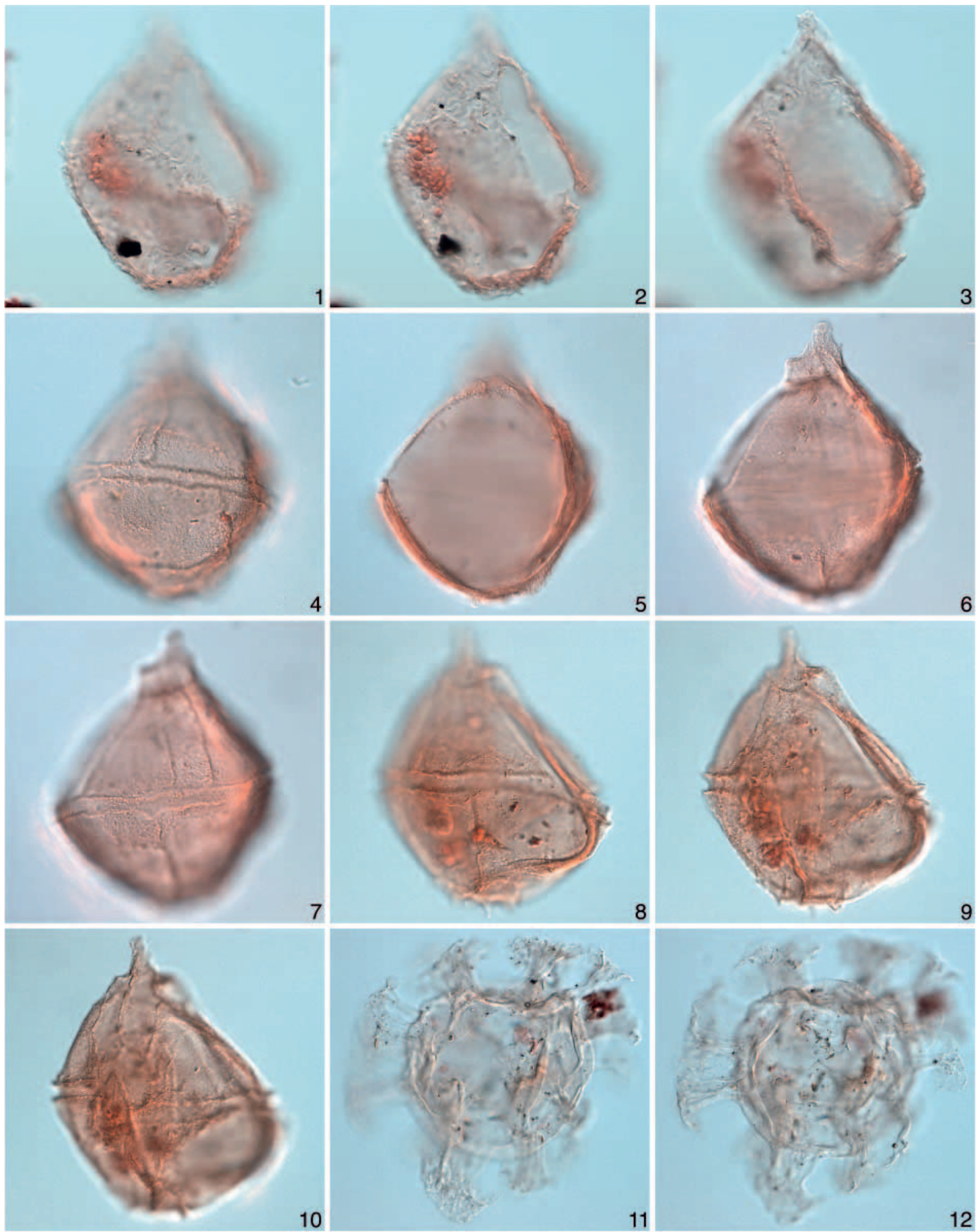

8
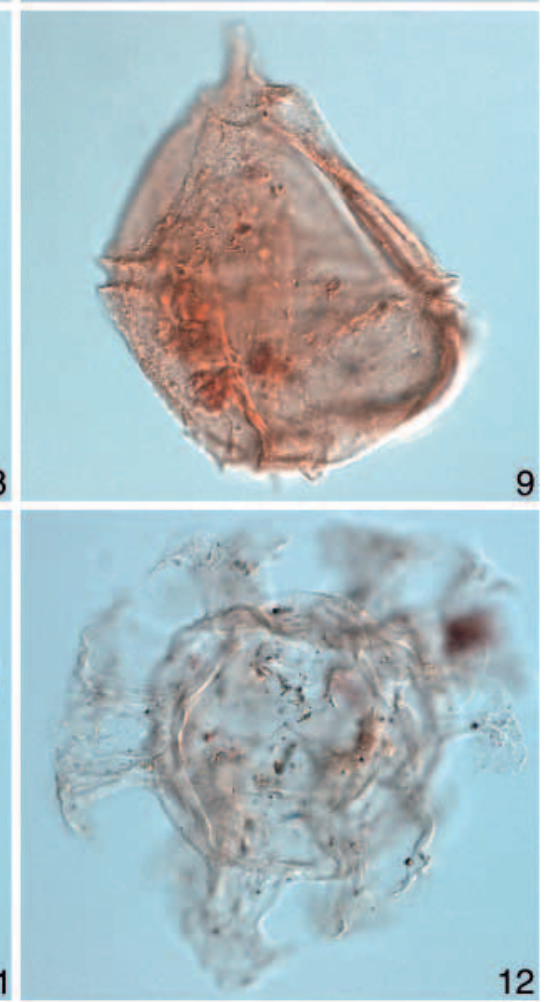

Plate 6. For full plate explanation see page 130.

restricted range of about 20-18.2 Ma in the eastern USA, where it defines the upper part of the dinoflagellate cyst zone DN2 (early to mid-Burdigalian; de Verteuil \& Norris, 1996; Fig. 3). In
Denmark, this species is also recorded from the early to midBurdigalian, where it is restricted to the upper part of stratigraphic sequence C (Dybkjær, 2004, fig. 14). Sequence C has 

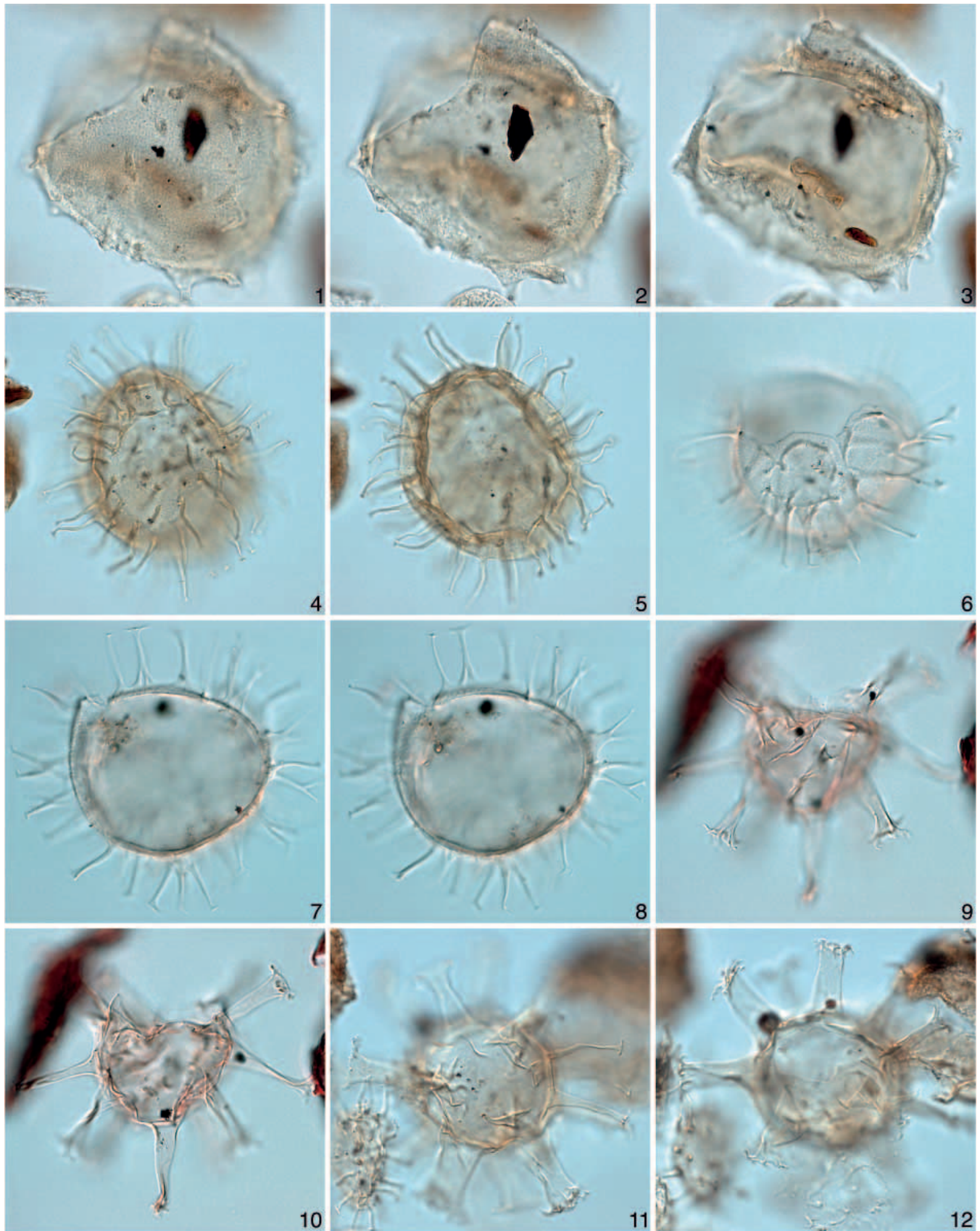

Plate 7. For full plate explanation see page 130.

been correlated to the North Sea benthic foraminiferal zone NSB10I and the lower part of planktonic foraminiferal zone NSP11, which in turn are correlated to the calcareous nanno- fossil zone NN3 (and possible upper NN2) and lower part of NN4 (King, 1989; Laursen \& Kristoffersen, 1999; Dybkjær, 2004). Hence, E. insigne ranges slightly higher in Denmark than 
G. Jiménez-Moreno et al.

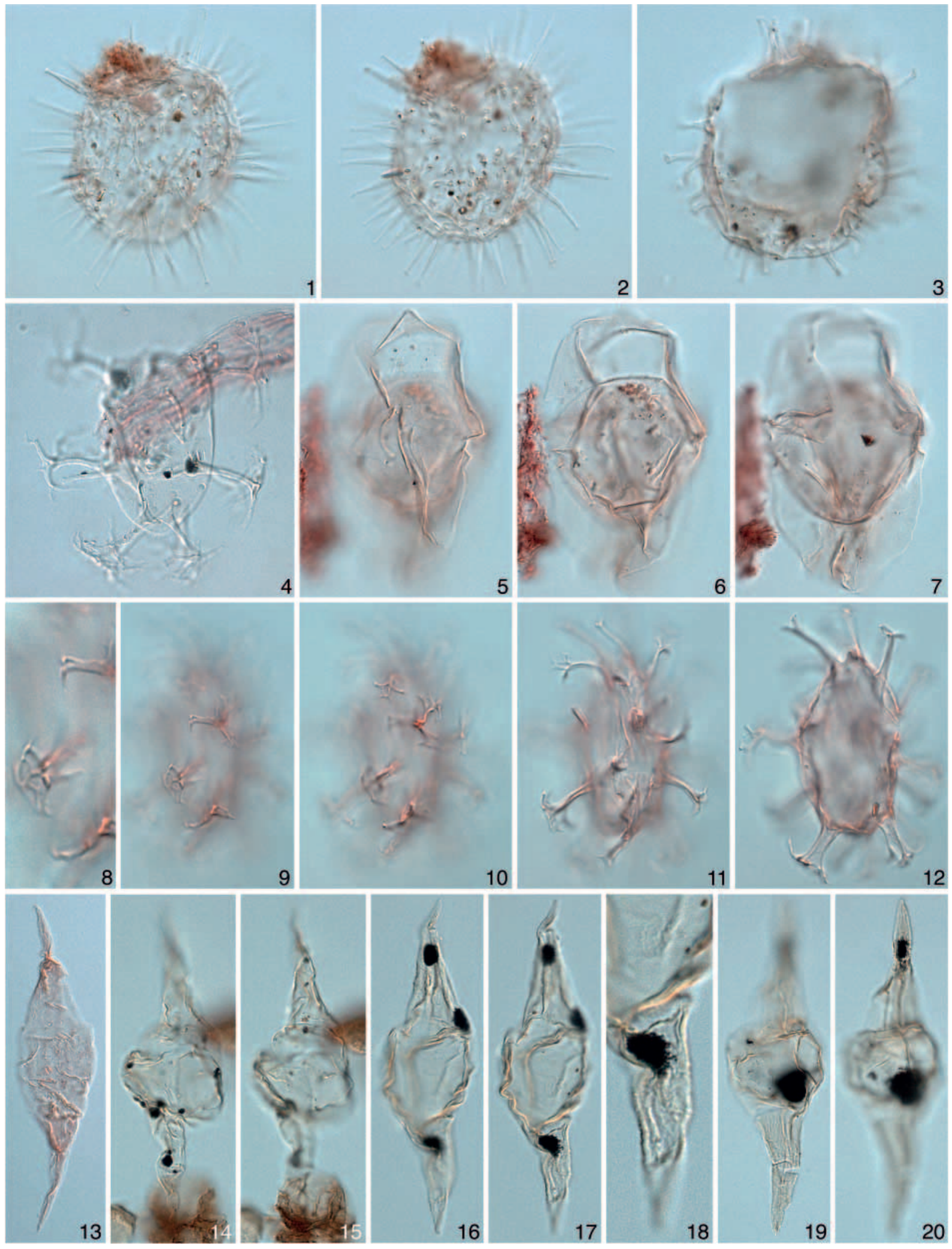

Plate 8. For full plate explanation see page 130 

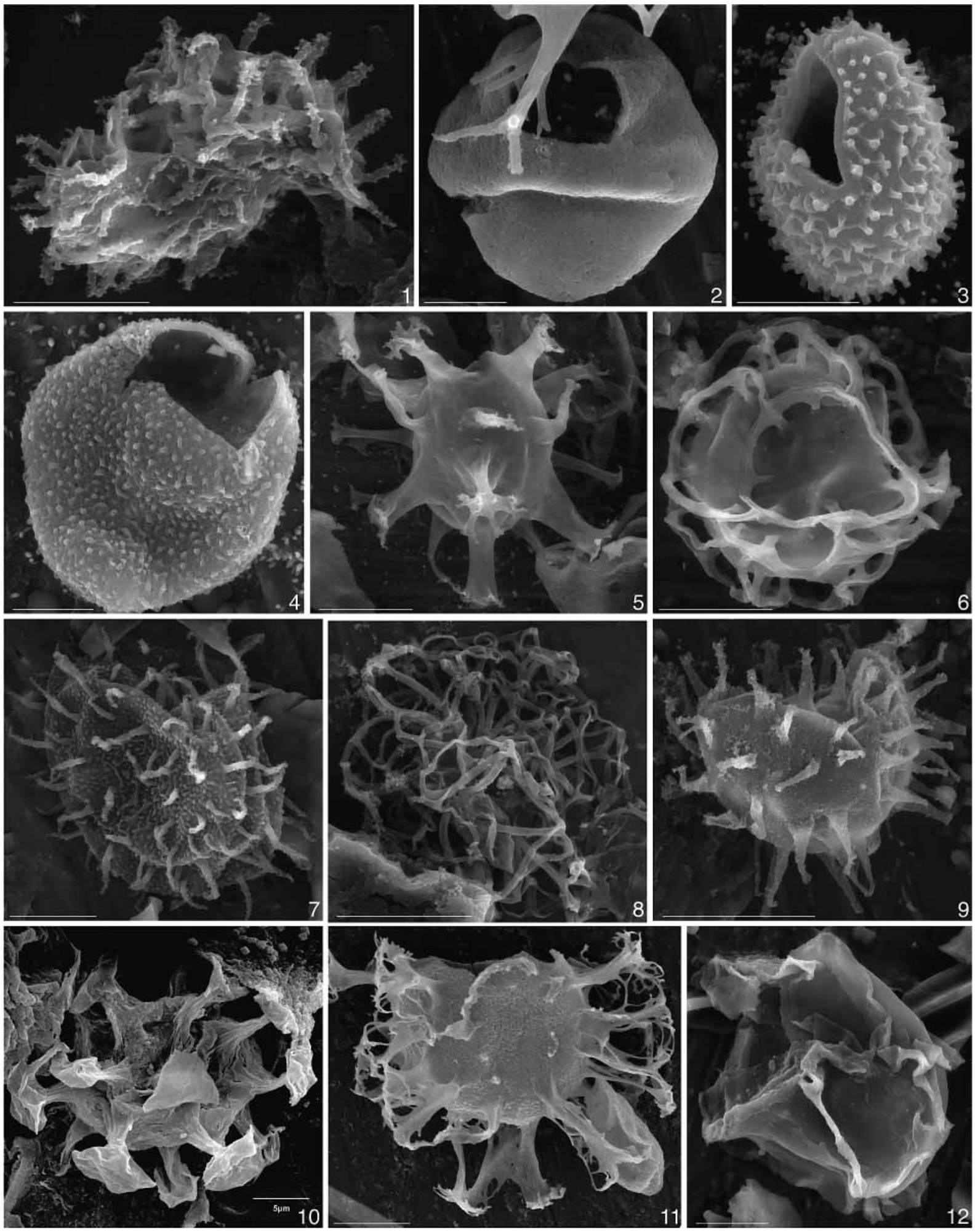

Plate 9. For full plate explanation see page 130.

in the eastern USA, unless this discrepancy represents small inaccuracies in correlation to the standard time-scale. For the Danish North Sea, Schiøler (2005) reported E. insigne from the Burdigalian (North Sea benthic foraminiferal zone NSB10), supporting the study by Dybkjær (2004), but he also recorded this species sporadically and rarely throughout the Oligocene and into the Eocene. Schiøler's study is based on ditch cutting samples, and caving may account for the pre-Miocene 
Explanation of Plates 1-9.

Explanation of Plate 1. Dinocysts from the Miocene of the Central Paratethys. Various magnifications. Teng-2 is Tengelic-2. figs 1-3. Habibacysta tectata, right latero-ventral view at upper, mid and lower foci; length $37 \mu \mathrm{m}$; Teng-2, $818.4 \mathrm{~m}$, slide 1, P10/2. figs 4-6. Batiacasphaera sphaerica, antapical view at upper, mid and lower foci; maximum diameter $33 \mu \mathrm{m}$; Baden-Soos \#2, slide 2, K35/3. figs 7-9. Cerebrocysta 'cassinascoensis', lateral view, at upper, slightly lower and mid foci; maximum diameter $40 \mu \mathrm{m}$; Teng- $2,841.0 \mathrm{~m}$, slide 1, L22/2. figs 10-12. Cerebrocysta poulsenii, right latero-dorsal view at upper, mid and lower foci; central body length $39 \mu \mathrm{m}$; Teng-2, $820.4 \mathrm{~m}$, slide 2, W18/4. figs 13-15. Pyxidinopsis sp. (rhombic-cruciform, fine ornament), ventral view at upper, slightly lower and lower foci; note tectate wall; length $36 \mu \mathrm{m}$; Baden-Soos \#4, slide 2, Y22/2. figs 16-17. Pyxidinopsis sp. (rhombic-cruciform, fine ornament), dorsal view at upper and mid foci; length $47 \mu \mathrm{m}$; Teng-2, $726.7 \mathrm{~m}$, slide 2, R34/1. fig. 18. Pyxidinopsis sp. (rhombic-cruciform, fine ornament), ventral view at upper focus; length $34 \mu \mathrm{m}$; Teng-2, 829.3 m, slide 2, Q18/2. figs 19, 20. Operculodinium piaseckii, right lateral view at upper and mid foci; central body length $44 \mu \mathrm{m}$; Teng-2, $835.7 \mathrm{~m}$, slide 1 , W24/2.

Explanation of Plate 2. Marine palynomorphs from the Miocene of the Central Paratethys. Various magnifications. Teng-2 is Tengelic-2. figs 1-5. Operculodinium? borgerholtense: 1-3, right lateral view at upper, slightly lower and mid foci; central body length $39 \mu \mathrm{m}$; Baden-Soos \#1, slide 2 , E31/1; 4, 5, left lateral? view at upper and mid foci; central body max. diameter $40 \mu \mathrm{m}$; Teng-2, $706.2 \mathrm{~m}$, slide 2, V38/0. figs 6-8. Organic lining of a calcareous cyst, antapical view at upper, mid and lower foci, showing faint reticulation on surface that reflects position of (now dissolved) calcareous crystals; maximum diameter $31 \mu \mathrm{m}$; Baden-Soos \#4, slide 2, N33/1. figs 9, 10. Unipontidinium aquaeductus, apical view at upper and mid foci; central body max. diameter $38 \mu \mathrm{m}$; Teng-2, $816.4 \mathrm{~m}$, slide 2, A42/4. figs 11, 12. Labyrinthodinium truncatum subsp. truncatum, uncertain view at upper and mid foci; maximum diameter including processes $38 \mu \mathrm{m}$; Teng-2, $841.0 \mathrm{~m}$, slide 1, F39/3. fig. 13. Cordosphaeridium minimum sensu Benedek \& Sarjeant (1981), uncertain view at mid focus; maximum diameter including processes $33 \mu \mathrm{m}$; Baden-Soos \#4, slide 2, L43/1. figs 14-16. Nannobarbophora gedlii, upper focus showing irregular split in wall, slightly lower focus and mid focus; central body maximum diameter $25 \mu$ m; Baden-Soos \#1, slide 1, E25/3. figs 17-19. Micrhystridium sp., upper, mid and lower foci; central body maximum diameter $18 \mu \mathrm{m}$; Baden-Soos \#4, slide 2, C22/1. figs 20, 21. Melitasphaeridium choanophorum, dorso-antapical view at upper and mid foci; central body equatorial diameter $31 \mu \mathrm{m}$; Baden-Soos \#2, slide 2, B33/3.

Explanation of Plate 3. Dinocysts from the Miocene of the Central Paratethys. Various magnifications. Teng-2 is Tengelic-2. figs 1, 2. Lejeunecysta marieae, ventral view at upper and lower foci; length $40 \mu \mathrm{m}$; Teng-2, $768.5 \mathrm{~m}$, slide 1, S34/1. figs 3-5. Lejeunecysta cinctoria, ventral view at upper, mid and lower foci; length $38 \mu \mathrm{m}$; Teng-2, $841.0 \mathrm{~m}$, slide 1, S21/2. fig. 6. Selenopemphix nephroides, apical view at mid focus; width $42 \mu \mathrm{m}$; Teng-2, $816.4 \mathrm{~m}$, slide 2, L40/3. figs 7, 8. Selenopemphix brevispinosa, antapical view at upper and lower foci; width excluding processes $38 \mu \mathrm{m}$; Teng-2, $818.4 \mathrm{~m}$, slide 1, T31/0. figs 9, 10. Selenopemphix conspicua, antapical view at upper and mid foci; width excluding processes $46 \mu \mathrm{m} ;$ Teng-2, $820.4 \mathrm{~m}$, slide 2, F10/1. figs 11, 12. Quadrina cf. condita, upper and lower foci; central body maximum diameter $34 \mu \mathrm{m}$; Baden-Soos \#2, slide 1, M34/3. figs 13, 14. Trinovantedinium? xylochoporum, uncertain view at upper and mid foci; central body length $53 \mu \mathrm{m}$; Teng- $2,768.5 \mathrm{~m}$, slide 1 , V14/3. figs $\mathbf{1 5}$, 16. Trinovantedinium harpagonium, ventral view at upper and mid foci; length including processes $68 \mu \mathrm{m}$; Teng-2, $835.7 \mathrm{~m}$, slide 2 , O40/2.

Explanation of Plate 4. Dinocysts from the Miocene of the Central Paratethys. Various magnifications. Teng-2 is Tengelic-2. figs 1-3. Barssidinium pliocenicum, ventral view at upper focus showing detail of wall surface, mid focus and lower focus; central body width $73 \mu \mathrm{m}$; Teng-2, $773.5 \mathrm{~m}$, slide 1, P39/1. figs 4-8. Sumatradinium druggii: 4-6, uncertain view of upper, mid and lower foci, showing very faintly microreticulate central body wall surface; central body maximum diameter $82 \mu \mathrm{m}$; Baden-Soos \#2, slide 2, R40/4; 7-8, ventral view at upper and lower foci; central body length $90 \mu \mathrm{m}$; Baden-Soos \#4, slide 2, P31/0. figs 9-12. cf. Sumatradinium soucouantiae: 9-11, dorsal view at upper, slightly lower and mid focus, with the close up in $\mathbf{1 0}$ showing very faintly microreticulate central body wall surface; central body length $64 \mu \mathrm{m}$; Baden-Soos \#4, slide 2, J22/0; 12, dorso-ventral view at upper focus showing scabrate central body surface; central body length $60 \mu \mathrm{m}$; Baden-Soos \#4, slide 2, F43/3. The tentative identification reflects the variable and weakly expressed ornamentation on the central body surface.

Explanation of Plate 5. Dinocysts from the Miocene of the Central Paratethys. Various magnifications. figs 1-10. Glaphyrocysta reticulosa sensu lato, ventral view at upper through lower foci: 1-5, note ornament on mid-dorsal surface; central body width $82 \mu$; Strass-Eberschwang \#3, slide 1, V41/3; 6-10, central body width $84 \mu \mathrm{m}$; Strass-Eberschwang \#3, slide 1, E38/0. figs 11-12. Membranophoridium sp., dorsal view at upper and lower foci; central body width $73 \mu \mathrm{m}$; Strass-Eberschwang \#3, slide 1, S41/0.

Explanation of Plate 6. Dinocysts from the Miocene of the Central Paratethys. Various magnifications. figs 1-3. Apteodinium spiridoides, left latero-dorsal view at upper, mid and lower foci; length $103 \mu \mathrm{m}$; Strass-Eberschwang \#7, slide 1, F20/3. figs 4-10. Cribroperidinium tenuitabulatum: 4-7, right lateral view at upper through lower foci; length $96 \mu \mathrm{m}$; Baden-Soos \#2, slide 2, D38/0; 8-10, left lateral view at upper, mid and lower foci; length $95 \mu \mathrm{m}$; Baden-Soos \#4, slide 1, X9/2. figs 11, 12. Cordosphaeridium cantharellus, dorsal view at upper and lower foci; central body maximum diameter $63 \mu \mathrm{m}$; Strass-Eberschwang \#3, slide 1, C33/1.

Explanation of Plate 7. Dinocysts from the Miocene of the Central Paratethys. Various magnifications. Teng-2 is Tengelic-2. figs 1-3. Exochosphaeridium insigne, right latero-dorsal view at upper through lower foci; central body maximum diameter $85 \mu \mathrm{m}$; Strass-Eberschwang \#1, slide GJM, W9/1. figs 4, 5. Operculodinium centrocarpum sensu stricto, ventral view at upper and mid foci; central body maximum diameter $61 \mu$ m; Teng-2, $768.5 \mathrm{~m}$, slide 1, R19/4. figs 6-8. Cleistosphaeridium placacanthum, lateral view at upper through lower foci; central body width $55 \mu$ m; Baden-Soos \#1, slide 1, B15/1. figs 9-12. Hystrichokolpoma sp. A: 9, 10, lateral view at upper and mid foci; central body width $35 \mu \mathrm{m}$; Baden-Soos \#4, slide 2, S14/1; 11, 12, antapical view at upper and lower foci; central body maximum diameter $38 \mu \mathrm{m}$; Teng-2, 768.5 m, slide 1, C35/4.

Explanation of Plate 8. Dinocysts from the Miocene of the Central Paratethys. Various magnifications. Teng-2 is Tengelic-2. figs 1, 2. Polysphaeridium sp. A, uncertain view at upper and lower foci; central body maximum diameter $46 \mu$ m; Baden-Soos \#2, slide 2, L41/3. fig. 3. Polysphaeridium zoharyi, antapical view at lower focus; central body maximum diameter $47 \mu \mathrm{m}$; Strass-Eberschwang \#3, slide 1, T38/1. fig. 4. Distatodinium paradoxum, lateral view at mid focus; central body length $51 \mu \mathrm{m}$; Strass-Eberschwang \#3, slide 1, Y17/0. figs 5-7. Hystrichosphaeropsis obscura, ventral view at upper, mid and lower foci; length $95 \mu \mathrm{m}$; Baden-Soos \#1, slide 1, K39/0. figs 8-12. Achomosphaera cf. andalousiensis sensu Strauss (1992), equatorial view at upper through mid foci, with 8 an enlargement of $\mathbf{9}$ showing fenestrate distal platform; central body length $41 \mu \mathrm{m}$; Baden-Soos \#4, slide 2, Y26/2. fig. 13. Palaeocystodinium powellii, left lateral view at mid-focus; length $138 \mu \mathrm{m}$; Strass-Eberschwang \#3, slide 1, Y38/2. figs 14, 15. Palaeocystodinium minor, equatorial view at upper and lower foci; length $101 \mu \mathrm{m}$; Teng-2, 820.4 m, slide 2, L34/2. figs 16-20. Palaeocystodinium miocaenicum, equatorial view at upper and lower foci: 16-18, at increased magnification showing strongly granulate-vermiculate ornament on horns and faint ornament on the central body; length $103 \mu \mathrm{m}$; Teng-2, $841.0 \mathrm{~m}$, slide 1, H23/0; 19, 20, showing ornamented horns but smooth central body; length $118 \mu \mathrm{m}$; Teng-2, $841.0 \mathrm{~m}$, slide $1, \mathrm{~V} 19 / 1$.

Explanation of Plate 9. Scanning electron micrographs of marine palynomorphs from the Tengelic-2 borehole at $777.0 \mathrm{~m}$ depth. fig. 1. Nannobarbophora gedlii, view uncertain. fig. 2. Pyxidinopsis sp. (rhombic-cruciform, fine ornament), dorsal view. fig. 3. Operculodinium piaseckii, right latero-dorsal view. fig. 4. Pyxidinopsis sp., dorsal view. fig. 5., Hystrichokolpoma sp. A, lateral view. fig. 6. Unipontidinium aquaeductus, lateral view. fig. 7. Operculodinium? borgerholtense, left-lateral? view. fig. 8. Nematosphaeropsis labyrinthus, view uncertain. fig. 9. Dapsilidinium pseudocolligerum, lateral view. fig. 10. Cordosphaeridium minimum sensu Benedek \& Sarjeant (1981), view uncertain. fig. 11. Glaphyrocysta reticulosa sensu lato, dorsal view. fig. 12. Pentadinium laticinctum, right latero-dorsal view. Scale bar is $5 \mu \mathrm{m}$ in fig. $10 ; 10 \mu \mathrm{m}$ in figs $1,2,4$ and 7 ; and $20 \mu \mathrm{m}$ in figs $3,5,6,8,9,11$ and 12 . 
occurrences. E. insigne has been reported from northern Germany by Köthe (2004), where it occurs within deposits of early to middle Early Miocene age and is assigned to dinocyst zone DN2 of de Verteuil \& Norris (1996).

Dinocyst zone Ein is thus assignable to the early or midBurdigalian, and has a maximum age of about $20 \mathrm{Ma}$ (early Burdigalian) based on the lowest occurrence (LO) of E. insigne in eastern USA, and minimum age of about $17.8 \mathrm{Ma}$ (midBurdigalian) based on the highest occurrence (HO) of C. cantharellus in low latitudes.

Glaphyrocysta reticulosa s.1. (P1. 5, figs 1-10; P1. 9, fig. 11) and Membranophoridium sp. (Pl. 5, figs 11, 12) are considered to be in place because of their persistence throughout the section, relatively common abundance, and consistent preservational state, as well as a general scarcity of identifiably reworked taxa in the samples. Yet, elsewhere, species of Glaphyrocysta and Membranophoridium have mostly disappeared by the end of the Oligocene (Stover et al., 1996; Williams et al., 2004). It is significant that Glaphyrocysta texta has been recorded from the early Burdigalian stratotype area of France (unillustrated in Londeix \& Jan du Chêne, 1998), where it has its $\mathrm{HO}$ within deposits dated at around 19-20 Ma by ${ }^{87} \mathrm{Sr} /{ }^{86} \mathrm{Sr}$ measurements and assigned to nannofossil zone NN2 and foraminiferal zone N5 (=zone M2 of Berggren et al., 1995). Both ?Glaphyrocysta spineta and Membranophoridium aspinatum have also been reported from the early to middle Early Miocene (dinocyst zone DN2 of de Verteuil \& Norris, 1996) of northern Germany (Köthe, 2004), confirming that these two genera range into the Early Miocene beyond the Paratethys.

Comments. An early or mid-Burdigalian age based on dinocysts is consistent with other biostratigraphic evidence that allows this section to be assigned to the Middle Ottnangian Stage (mid-Burdigalian). On the basis of all evidence, a midBurdigalian age is therefore accepted for this section. This inferred position fits well with the sequence stratigraphic correlation of Vakarcs et al. (1998) and Kovac et al. (2004) who propose the Eggenburgian-Ottnangian depositional cycle to be an expression of the global third-order sequence TB 2.2 of Haq et al. (1988). The presence of G. reticulosa s.1. and Membranophoridium sp. at Strass-Eberschwang constitute one of the highest confirmed records of these genera and perhaps represent refugial populations within the Paratethys. The presence of $G$. reticulosa s.l. in our material replicates the findings of Hochuli (1978) who recorded this species (as Cyclonephelium reticulosum) from the Ottnangian of Austria and southern Germany in abundances of up to $39 \%$ of the dinoflagellate count.

Zone Ein is recognized throughout the Strass-Eberschwang section, and may extend above and below the examined interval.

\section{Cribroperidinium tenuitabulatum Assemblage Biozone (Cte)}

Definition. Interval characterized by combined presence of Achomosphaera cf. andalousiensis, Cerebrocysta poulsenii, Cribroperidinium tenuitabulatum, Habibacysta tectata, Labyrinthodinium truncatum subsp. truncatum, Palaeocystodinium miocaenicum,
Trinovantedinium harpagonium and Unipontidinium aquaeductus. Top defined by $\mathrm{HO}$ of Cribroperidinium tenuitabulatum.

Reference section. Tengelic-2 borehole, Hungary, depth 841.0$826.4 \mathrm{~m}$ (eight samples).

Other sections. The Baden-Sooss section, Vienna Basin, Austria (2.9 m thickness) is correlated with biozone Cte, based on the presence of Cribroperidinium tenuitabulatum and of all other characteristic taxa listed above, with the exception of Unipontidinium aquaeductus.

Correlation. Dinocyst zone Cte is directly correlated with nannofossil zone NN5 in both the Tengelic-2 borehole and at Baden-Sooss (see above). At Baden-Soos, the zone is additionally correlated with the planktonic foraminiferal zone M6 and the Upper Lagenidae Zone of Grill (1941).

Age. The LO of Unipontidinium aquaeductus (Pl. 2, figs 9, 10; Pl. 9, fig. 6) defines the base of dinocyst zone Uaq of Zevenboom (1995), and in the Cessole section of northwest Italy this datum has been correlated to within Subchron C5Bn2n (Zevenboom, 1995), which is dated at $15.1 \mathrm{Ma}$ using the time-scale of Gradstein et al. (2004). In the Cessole section, this datum also occurs within nannofossil zone NN5 and in the upper part of the foraminiferal zone M5 (near to the M5-M6 boundary). However, the time-scale of Gradstein et al. (2004) places the base of nannofossil zone NN5 at 14.9 Ma. There is clearly a discrepancy either with the magnetostratigraphic interpretation of the Cessole section (which is not entirely unequivocal, see Zevenboom, 1995 , p. 75), or with the biostratigraphic calibration to the magnetostratigraphy in the Gradstein et al. (2004) time-scale. It is worth noting that the LO of $U$. aquaeductus is correlated with nannofossil zone NN5 in other well-constrained sections, e.g. eastern USA (de Verteuil \& Norris, 1996) and northern Germany (Strauss et al., 2001), and is placed within the mid-Langhian of northern Belgium (Louwye et al., 2000). Gradstein et al. (2004) correlated the LO of $U$. aquaeductus to the base of Subchron C5ADr dated at $14.8 \mathrm{Ma}$. Until these discrepancies are resolved, $U$. aquaeductus is here considered to have its LO within the interval 15.1-14.8 Ma (mid-Langhian).

Habibacysta tectata (Pl. 1, figs 1-3) has its LO at about $14 \mathrm{Ma}$ in the eastern USA (de Verteuil \& Norris, 1996), and a slightly lower LO within the mid-Langhian of Belgium (Louwye et al., 2000). Its range elsewhere is not well known, although Filisphaera minuta, described from the Middle Miocene of northern Germany, is a possible junior synonym of $H$. tectata (Head, 1996). F. minuta has a LO within the mid-Langhian in northern Germany, correlated with the lower part of nannofossil zone NN5 (Strauss et al., 2001). Schiøler (2005) reported H. tectata downhole from the Burdigalian until the Oligocene of the Danish North Sea, but that study is based on ditch cutting samples, and the possibility of caving must therefore be considered. A solitary record of $H$. tectata from the Lower Miocene of northern Belgium (Louwye \& Laga, 1998) represents suspected contamination (S. Louwye, pers. comm. 2006).

Although the subspecies Labyrinthodinium truncatum subsp. truncatum (Pl. 2, figs 11,12 ) and L. truncatum subsp. modicum 
are not identified separately on the range charts for the Tengelic-2 borehole, both are present and L. truncatum subsp. truncatum occurs throughout dinocyst zone Cte including the lowest sample. L. truncatum subsp. truncatum also occurs in the Baden-Soos section. L. truncatum subsp. truncatum has a LO in the latest Burdigalian at about 16.3 Ma in the eastern USA (de Verteuil \& Norris, 1996). L. truncatum subsp. modicum has a LO at about $16.7 \mathrm{Ma}$ in the eastern USA (de Verteuil \& Norris, 1996), and has been recorded from deposits as old as about 20 Ma (early Burdigalian) in France (Londeix \& Jan du Chêne, 1998). L. truncatum is recorded frequently in Middle Miocene deposits (see Head et al., 1989b for discussion), and it is noteworthy that this species has its LO in the Cessole composite section of northwest Italy immediately below that of Unipontidinium aquaeductus, i.e. within nannofossil zone NN5, upper part of planktonic foraminiferal zone M5, and Subchron $\mathrm{C} 5 \mathrm{Bn} 2 \mathrm{n}$ (see discussion above).

Cerebrocysta poulsenii (P1. 1, figs 10-12) has a LO within the mid-Burdigalian (c. $18.3 \mathrm{Ma}$ ) in the eastern USA (de Verteuil \& Norris, 1996), although its LO in the Mediterranean is in the earliest Langhian at about $16 \mathrm{Ma}$ (as 'Imperfectodinium septatum' in Zevenboom, 1995). Trinovantedinium harpagonium (P1. 3 , figs 15,16 ) has a LO within the upper part of dinocyst zone DN4 in the eastern USA (de Verteuil \& Norris, 1996, table 4), which is of early Langhian age. Achomosphaera cf. andalousiensis (P1. 8, figs 8-12) has a rare and sporadic occurrence in zone Cte, but is restricted to this zone. This taxon has a LO within zone Naq (late Langhian to earliest Serravallian) in northern Germany (as Spiniferites cf. andalousiensis in Strauss et al., 2001).

Palaeocystodinium miocaenicum (Pl. 8, figs 16-20) has a $\mathrm{HO}$ within zone Naq of northern Germany, which is correlated with calcareous nannofossil zone NN5 (Strauss et al., 2001). However, this species appears to range into the early Tortonian of Italy (as 'P. striatogranulosum' in Zevenboom, 1995). Cribroperidinium tenuitabulatum (P1. 6, figs 4-10) has its highest accepted in situ occurrence at $826.4 \mathrm{~m}$, with higher records (at $824.4 \mathrm{~m}, 818.4 \mathrm{~m}$ and $816.4 \mathrm{~m}$ ) being probably reworked on account of their rarity (a single specimen per examined microscope slide). Specimens have variably expressed primary and accessory sutural ridges and compare favourably with other illustrated records of this species (e.g. Manum et al., 1989; de Verteuil \& Norris, 1996; Torricelli \& Biffi, 2001). This species has a $\mathrm{HO}$ in the early Serravallian (foraminiferal zone M8; about $13.3 \mathrm{Ma}$ ) of the Langhe region, northwest Italy (as Cribroperidinium? sp. A in Powell, 1986b). Elsewhere it has a lower range top, such as within the mid-Burdigalian dinocyst zone DN3 off New Jersey, USA and in the eastern USA (de Verteuil, 1996, 1997, respectively), and within the late Early Miocene of the Norwegian Sea (Manum et al., 1989). Higher records, such as the Tortonian of Sicily (Corradini, 1989), may represent reworking.

Dinocyst zone Cte is therefore no older than about 15.114.8 Ma (mid-Langhian) based on the LO of Unipontidinium aquaeductus at northern mid-latitudes, and possibly no older than about $14 \mathrm{Ma}$ (late Langhian) based on the LO of Habibacysta tectata in the eastern USA. The top of zone Cte is less reliably constrained but has a minimum age possibly of around 13.3 Ma based on the HO of Cribroperidinium tenuitabulatum.
This constrains zone Cte to an interval within the mid- or late Langhian to early Serravallian.

Comments. A mid- or late Langhian to early Serravallian age for zone $\mathrm{Cte}$ is consistent with other biostratigraphic evidence that allows this interval to be assigned to the late Langhian. On the basis of all evidence, a late Langhian age is therefore proposed for zone Cte. Unipontidinium aquaeductus was not recorded at Baden-Soos. It may have been ecologically excluded from this site, or perhaps has evaded detection owing to its rarity in the lower part of this zone. Instead, the Baden-Soos assemblage is correlated with zone Cte on account of the overall similarity of the dinocyst flora, particularly including the presence of Habibacysta tectata and Labyrinthodinium truncatum subsp. truncatum. In terms of sequence stratigraphy, the depositional cycle representing zones Cte, Uaq and Cpo is interpreted to correspond with the Langhian third-order cycle TB 2.3 of Haq et al. (1988) (Kovac et al., 2004).

\section{Unipontidinium aquaeductus Interval Biozone (Uaq)}

Definition. Base defined by top of zone Cte; top defined by $\mathrm{HO}$ of Unipontidinium aquaeductus.

Other characteristic taxa. Characteristic species of zone Uaq include all those in the superjacent zone Cpo. The following species have their HO in zone Uaq: Batiacasphaera micropapillata, Lejeunecysta fallax, Lejeunecysta marieae, Palaeocystodinium powellii, Selenopemphix nephroides, Sumatradinium druggii, cf. Sumatradinium soucouyantiae and Trinovantedinium harpagonium. The following species are restricted to zone Uaq: Barssidinium pliocenicum, Palaeocystodinium minor, Selenopemphix conspicua and Trinovantedinium? xylochoporum.

Reference section. Tengelic-2 borehole, Hungary, depth 824.4 $739.0 \mathrm{~m}$ (35 samples).

Correlation. The basal $1.4 \mathrm{~m}$ of zone Uaq represents the Badenian Clay Formation, which is assigned to nannofossil zone NN5 and is late Langhian in age. The remainder of zone Uaq $(823-739 \mathrm{~m})$ is represented by the Szilágy Formation, which is assigned to nannofossil zone NN5 from its base at $823 \mathrm{~m}$ up to $802 \mathrm{~m}$ (latest Langhian) and to NN6 above (Early Serravallian). The part of zone Uaq that belongs to the Szilágy Formation is characterized by the Spirorutilus and Bulimina-Bolivina zones of the regional eco-zonation of Grill (1941), and thus belongs to the Middle and Upper Badenian regional stage.

Age. Unipontidinium aquaeductus ranges to the top of dinocyst zone DN5 in the eastern USA (de Verteuil \& Norris, 1996), its HO having an approximate age of $13.5 \mathrm{Ma}$ (earliest Serravallian). In northern Germany, it has a $\mathrm{HO}$ near the top of dinocyst zone Naq (Strauss et al., 2001) and is late Langhian or early Serravallian in age. In the Cassinasco section of northwest Italy, $U$. aquaeductus has a highest persistent occurrence within the middle of subzone Oei, this event being calibrated to Subchron C5AAn (Zevenboom, 1995, ch. 5, fig. 5), which is dated at $13.1 \mathrm{Ma}$ (early Serravallian). It is 
suspected that rare specimens occurring sporadically up to 12.0 Ma (late Serravallian) in the Cassinasco and Mazzapiedi sections of northwest Italy (Zevenboom, 1995) are reworked. If so, zone Uaq is late Langhian and early Serravallian in age, and no younger than about 13.1 Ma.

Comments. An early Serravallian age, possibly about $13.1 \mathrm{Ma}$, for the top of zone Uaq based on dinocysts is in agreement with other biostratigraphic evidence that allows the base of this zone to be assigned to the late Langhian and its top to the early Serravallian. It should be noted that the highest persistent occurrence of Unipontidinium aquaeductus is at $755 \mathrm{~m}$. The two records above this level are at $747 \mathrm{~m}$ (three specimens in an entire slide) and $739 \mathrm{~m}$ (three specimens in an entire slide). These specimens might therefore be reworked and, if so, would require the top of zone Uaq to be lowered to $755 \mathrm{~m}$.

The base of zone Uaq lies $1.4 \mathrm{~m}$ below an unconformable boundary between the Badenian Clay Formation and Szilágy Formation (at $823 \mathrm{~m}$ ). A brief hiatus therefore possibly occurs just above the base of zone Uaq.

\section{Cerebrocysta poulsenii Assemblage Biozone (Cpo)}

Definition. Base defined by top of subjacent dinocyst zone Uaq; otherwise defined by the presence of Cerebrocysta poulsenii, Hystrichokolpoma sp. A, Homotryblium plectilum, Hystrichokolpoma rigaudiae, Labyrinthodinium truncatum, Nematosphaeropsis labyrinthus, Operculodinium piaseckii and the acritarch Nannobarbophora gedlii. None of these extend into the superjacent zone.

Other characteristic taxa. Cleistosphaeridium placacanthum is abundant throughout this zone and ranges into the superjacent zone Cpl.

Reference section. Tengelic-2 borehole, Hungary, depth 738.0 $723.7 \mathrm{~m}$ (15 samples).

Correlation. Biozone Cpo lies within nannofossil zone NN6 and Bolivina-Bulimina Zone of the regional benthic eco-zonation of Grill (1941).

Age. The presence of abundant Cleistosphaeridium placacanthum (Pl. 7, figs 6-8) is perhaps the most characteristic feature of this zone, and indicates an age no younger than latest Serravallian. C. placacanthum defines the top of dinocyst zone DN5 in the eastern USA, this zone being calibrated to both nannofossil zone NN5 and the lower part of NN6 (de Verteuil \& Norris, 1996). The top of zone DN5 therefore has an approximate age of 13.5 Ma (earliest Serravallian). The $\mathrm{HO}$ of Unipontidinium aquaeductus (Pl. 2, figs 9, 10; Pl. 9, fig. 6) also occurs at the top of dinocyst zone DN5 in the eastern USA (de Verteuil \& Norris, 1996). In northern Germany, C. placacanthum has a well-defined $\mathrm{HO}$ at the same level as that of $U$. aquaeductus, near the top of dinocyst zone Naq (Strauss et al., 2001). The Naq zone does not have precise independent age control, but its top appears to be of late Langhian or early Serravallian age. The HO of $C$. placacanthum is therefore approximately at similar levels both in Germany and the eastern USA. In the Mazzapiedi section of northwest Italy, C. placacanthum has a highest common occurrence at the top of Subzone Aum, which is constrained by magnetostratigraphy to Subchron C5An1n (Zevenboom, 1995, ch. 5, fig. 6) and has an age of 12.1 Ma (late Serravallian). However, in the Cassinasco section of the same region, C. placacanthum is common throughout the section, the top of which is assigned to Subzone N1a, which is correlated with the lower part of nannofossil zone NN7 and with Subchron C5r3r (Zevenboom, 1995, ch. 5, fig. 5). Subchron C5r3r has an age ranging from $12.0 \mathrm{Ma}$ to $11.6 \mathrm{Ma}$, and is of latest Serravallian age. C. placacanthum therefore ranges at least close to the very latest Serravallian in the Cassinasco section and, interestingly, ranges higher than the $\mathrm{HO}$ of Unipontidinium aquaeductus in this section (see discussion of zone Uaq, above). The $\mathrm{HO}$ of $C$. placacanthum therefore shows some diachroniety (c. 13.5 Ma to $c$. 11.6 Ma), but there are no reliable reports of it occurring in deposits younger than latest Serravallian. Sporadic younger records in the literature are attributed to reworking (de Verteuil \& Norris, 1996, p. 32; Louwye \& Laga, 1998, fig. 3).

Cerebrocysta poulsenii ( $\mathrm{Pl}$. 1, figs 10-12) has a $\mathrm{HO}$ in the earliest Tortonian in the eastern USA, although this event is not well constrained (de Verteuil \& Norris, 1996). However, in the Mazzapiedi and Cassinasco sections of northwest Italy, this species has a $\mathrm{HO}$ at the top of subzone Aan which correlates with the lower to middle part of Subchron C5r3r and lower part of nannofossil zone NN7 (Zevenboom, 1995, ch. 5, figs 5 and 6). This indicates an age of $11.8 \mathrm{Ma}$ (latest Serravallian) for the HO of Cerebrocysta poulsenii. In northern Germany, $C$. poulsenii has a well-defined HO within dinocyst zone Cpa (Strauss et al., 2001), although this zone lacks firm calibration. However, the $\mathrm{HO}$ of $C$. poulsenii occurs just below the LO of Achomosphaera andalousiensis in northern Germany (Strauss et al., 2001) whereas in Denmark (Piasecki, 1980, as Gen. et sp. indet.) its HO occurs some distance above the LO of A. andalousiensis. Because the LO of A. andalousiensis is generally considered to occur in the latest Serravallian (Williams et al., 2004), the HO of $C$. poulsenii in Germany and Denmark is also taken to be within the late Serravallian or earliest Tortonian.

Labyrinthodinium truncatum (Pl. 2, figs 11-12) has a range top in the late Tortonian of the eastern USA (de Verteuil \& Norris, 1996). Other species within this zone are also relatively long ranging.

Comments. An early (possibly late early) Serravallian to earliest Tortonian age based on dinocysts is supported by evidence for a latest Badenian (late early Serravallian) age based on other fossils. A late early Serravallian age is therefore indicated for this interval. The top of zone Cpo is truncated by an unconformity. This zone is part of the latest Badenian third-order cycle of Kovac et al. (2004), which corresponds with the global glacioeustatic cycle TB 2.5 of Haq et al. (1988).

\section{Cleistosphaeridium placacanthum Assemblage Biozone (Cpl)}

Definition. Base defined by top of subjacent dinocyst zone Cpo; otherwise defined by abundant Cleistosphaeridium placacanthum. 
Other characteristic taxa. Hystrichosphaeropsis obscura, Operculodinium? borgerholtense, Pentadinium laticinctum and the acritarch Nannobarbophora gedlii.

Reference section. Tengelic-2 borehole, Hungary, depth 717.8$702.4 \mathrm{~m}$ (eight samples).

Correlation. Due to the endemic character of the fauna, only correlations with regional biozones are possible. The mollusc fauna described by Bohn-Havas (1982) between $718.1 \mathrm{~m}$ and $701.2 \mathrm{~m}$ indicates the Lower Sarmatian Mohrensternia Zone (Harzhauser \& Piller, 2004a). The foraminiferal assemblage between $723 \mathrm{~m}$ and $702 \mathrm{~m}$, with large species of Elphidium and Anomalinoides, indicates the lowermost Sarmatian Anomalinoides dividens Zone and the Lower Sarmatian Elphidium reginum Zone (Harzhauser \& Piller, 2004a).

Age based on dinocysts. The presence of abundant Cleistosphaeridium placacanthum ( $\mathrm{Pl}$. 7, figs 6-8) indicates an age no younger than late Serravallian (see discussion of zone Cpo, above). Operculodinium? borgerholtense (P1. 2, figs 1-5; P1. 9, fig. 7) has been reported previously only from Belgium, where it occurs in the Lower and Middle Miocene (Louwye, 2001). The stratigraphic range of the acritarch Nannobarbophora gedlii (Pl. 2, figs 14-16; P1. 9, fig. 1) is also not known in detail, although it has been reported only in deposits of Early and Middle Miocene age (Head, 2003). Hystrichosphaeropsis obscura (Pl. 8, figs 5-7) ranges into the late Tortonian of eastern USA (de Verteuil \& Norris, 1996) and Pentadinium laticinctum ranges well into the Late Miocene of northern Germany (Strauss et al., 2001). Other species in this zone are relatively long ranging.

Comments. This interval is Early Sarmatian (early late Serravallian) in age, based on evidence from other fossils. An age no younger than late Serravallian, as based on dinocysts, is consistent with this interpretation. The age as determined from molluscs and foraminifera clearly documents that dinocyst zone $\mathrm{Cpl}$ is restricted to the lower part of the Sarmatian. Dinocysts were not investigated from the upper part of the Sarmatian.

\section{PALAEOENVIRONMENTAL INTERPRETATION BASED ON DINOCYSTS}

The dinocyst assemblages reflect warm, neritic depositional conditions throughout the sections studied. Species of the genus Impagidinium, usually indicative of oceanic conditions, are rare; and the outer-neritic species Nematosphaeropsis labyrinthus rarely comprises more than $5 \%$ of the assemblage. The dominance of pollen and spores compared to dinocysts in all sections further attests to the proximity of the shore.

The Strass-Eberschwang section (dinocyst zone Ein; midBurdigalian, Ottnangian) has a low percentage of dinocysts relative to spores and pollen (1.9-12\%; Fig. 6), suggesting that this site was close to shore. The upper part of the section has particularly low percentages $(1.9-2.3 \%)$ of dinocysts, which is consistent with the sedimentological evidence of an upwardshallowing trend for this sequence. Impagidinium species are absent, suggesting a lack of open-marine conditions, whereas the continuous presence of areoligeracean species (Glaphyrocysta reticulosa s.1. and Membranophorodium sp.) is suggestive of restricted-marine conditions (e.g. Brinkhuis, 1994; Stover et al., 1996; Sluijs et al., 2005). Polysphaeridium zoharyi, an extant tropical-subtropical species, is consistently present through the mid-Burdigalian at this site, with percentages of around $5-10 \%$. Today, this species is associated with mangrove (MacLean, 1989) and it is therefore notable that pollen analyses at this site reveal Avicennia, which developed an impoverished mangrove on the coast. Avicennia is not present in the other sections, although Polysphaeridium zoharyi does in fact occur within them.

The Baden-Soos section (zone Cte; Langhian, pars; Early Badenian) contains a neritic assemblage dominated by species of the genus Spiniferites. The assemblage reflects more openwater conditions than are represented in the StrassEberschwang section, as evidenced by the presence of Impagidinium species which attest to the penetration of oceanic water masses at this site. However, the consistently high pollen: dinocyst ratio (80: 20) may indicate relatively close proximity to shore, but may alternatively reflect a focusing of pollen within the embayment-like palaeogeography of the Vienna Basin during the Badenian.

In the Tengelic-2 borehole, assemblages from zone Cte (Langhian, pars) reflect similar environmental conditions to those at Baden-Sooss, except that the lower pollen: dinocyst ratio (40: 60 to 70: 30) suggests more open-marine conditions. This is supported by the presence of the oceanic species Invertocysta tabulata at $841.0 \mathrm{~m}$. An oceanic influence is indicated by the persistence of rare Impagidinium species throughout dinocyst zones Cte, Uaq and Cpo in the Tengelic-2 borehole. Indeed, rare Impagidinium spp. and the oceanic to outer neritic Nematosphaeropsis labyrinthus are present to the top of zone Cpo, indicating that relatively open-marine conditions persisted to the end of this zone. However, a distinct reduction in species richness occurs within zone $\mathrm{Cpo}$, suggesting the onset of somewhat restricted-marine conditions. Species that disappear as a result of ecological exclusion in this zone include Cordosphaeridium minimum sensu Benedek \& Sarjeant (1981), Reticulatosphaera actinocoronata, the organic linings of calcareous cysts (all of which briefly return in the overlying zone), Labyrinthodinium truncatum and Cerebrocysta poulsenii. Zone Cpo presumably reflects shallowing of the sea, prior to the emergence and erosion that led to the unconformity between zone $\mathrm{Cpo}$ and $\mathrm{Cpl}$ at the Badenian-Sarmatian boundary. Zone $\mathrm{Cpl}$ contains a low diversity assemblage indicating environmentally unfavourable conditions for most marine dinoflagellates. Cosmopolitan neritic species (e.g. Spiniferites spp., Cleistosphaeridium placacanthum, Operculodinium spp.) and extant euryhaline species (Lingulodinium machaerophorum) dominate the assemblage in this zone. Impagidinium spp. and Nematosphaeropsis labyrinthus are absent, indicating the disappearance of open-marine influence by this time. Salinities exceeded about $10-15$ for most of zone Cpl, as evidenced by the presence of Lingulodinium machaerophorum, and somewhat enhanced nutrient levels might also be indicated by the higher levels of L. machaerophorum in this zone (see Dale, 1996). A reciprocal relationship exists between the abundance of L. machaerophorum and Polysphaeridium spp. (Fig. 8), suggesting fluctuating salinities in which $L$. machaerophorum represents hyposaline conditions and Polysphaeridium reflects hypersaline conditions (see Head \& Westphal, 1999). Polysphaeridium sp. 
almost completely dominates the sample at $708.7 \mathrm{~m}$. The absence of the genus Homotryblium within zone $\mathrm{Cpl}$ is surprising given its affinity for hypersaline environments within the Messinian of the Mediterranean (e.g. Suc et al., 1995; Bertini et al., 1998) and, perhaps, attests to an unfavourable water chemistry during hypersaline phases in the Paratethys. The dominance of Cleistosphaeridium ancyrea in the uppermost samples of zone $\mathrm{Cpl}$ is difficult to explain with a simple shallowingupward model for zone $\mathrm{Cpl}$ because this genus is generally associated with more distal positions on the palaeoshelf (Brinkhuis, 1994; Sluijs et al., 2005). This dominance of $C$. ancyrea either reveals gaps in our understanding of its palaeoecology or reflects the unstable conditions that prevailed during zone Cpl.

\section{DISCUSSION AND CONCLUSIONS}

Dinoflagellate cysts and other marine palynomorphs have been studied in 82 samples from three central Paratethyan localities. A diverse dinocyst flora comprising 74 taxa has been recorded and five biozones (zones Ein, Cte, Uaq, Cpo and Cpl) established, representing the first Miocene dinocyst zonation for the Paratethys. The biozones, which are independently dated by foraminifera and nannofossils, show strong similarities with contemporaneous assemblages from the Mediterranean and North Atlantic regions for the Early and Middle Miocene. This was at a time when broad connections with the Mediterranean Sea enabled effective floral exchange between both regions. This study therefore confirms the biostratigraphic utility of dinocysts for the Lower and Middle Miocene of Paratethys.

Zone Ein is recognized only from the Strass-Eberschwang outcrop, which is assigned to the Middle Ottnangian Stage (mid-Burdigalian). The presence of Glaphyrocysta reticulosa s.1. and Membranophoridium sp. in this zone represent unusually high stratigraphic occurrences when compared with the Mediterranean; they perhaps represent refugial populations within the Paratethys.

Zone Cte is recognized from the Baden-Sooss outcrop and between $841.0 \mathrm{~m}$ and $826.4 \mathrm{~m}$ in the Tengelic-2 borehole. These deposits are assigned to the late Early Badenian (late Langhian), and a mid- or late Langhian to early Serravallian age based on dinocysts is consistent with this assignment. This zone is synchronous with the Langhian climatic optimum, and the pollen data for the Tengelic-2 borehole show high but declining proportions of thermophilous plants through zone Cte (JiménezMoreno et al., 2005). The 'Monterey cooling event' occurred at 14.2 $\mathrm{Ma}$ and relates to the onset of development of the East Antarctic Ice Sheet (Shevenell et al., 2004). Declining temperatures may therefore be responsible for changes in the dinocyst assemblage through zone Cte, including the demise of Cribroperidinium tenuitabulatum. Global cooling continued through the late Langhian and Serravallian and is reflected in the pollen analysis for the Tengelic-2 borehole (Jiménez-Moreno et al., 2005). The subsequent dinocyst record should therefore be viewed within this context of declining temperatures as well as a progressive shallowing of Paratethys.

Zone Uaq is recognized between $824.4 \mathrm{~m}$ and $739.0 \mathrm{~m}$ in the Tengelic-2 borehole. The basal c. $1.4 \mathrm{~m}$ of this zone is assigned to the late Early Badenian (late Langhian) and the remainder is Middle and Late Badenian (late Langhian and early Serraval- lian) in age. An early Serravallian age for the top of zone Uaq, possibly about $13.1 \mathrm{Ma}$ based on the highest occurrence of Unipontidinium aquaeductus, is in agreement with this assignment. This datum does not coincide with any regional stage boundaries and adds new resolution to the biostratigraphy of the Tengelic-2 borehole. Evidence from radiolarians suggests that a marine connection with the Indian Ocean may have existed at around this time, although the dinocyst flora does not appear to show any influences other than those expected from a Mediterranean and North Atlantic connection.

Zone Cpo is recognized between $738.0 \mathrm{~m}$ and $723.7 \mathrm{~m}$ in the Tengelic-2 borehole, and is assigned to the latest Badenian (early Serravallian). Several dinocyst species and the acritarch Nannobarbophora gedlii disappear within this zone, indicating the onset of unfavourable conditions for fully marine organisms. This probably relates to the decreasing connection of the Central Paratethys with the Mediterranean Sea in the latest Badenian and to the first shifts in water chemistry towards polyhaline conditions at that time (Rögl, 1998; Kovac et al., 2004).

Zone $\mathrm{Cpl}$ is recognized between $717.8 \mathrm{~m}$ and $702.4 \mathrm{~m}$ in the Tengelic-2 borehole, and is assigned to the Early Sarmatian (late early Serravallian). It is characterized by a shift to low diversity dinocyst assemblages and reflects the establishment of a restricted-marine environment in which salinities fluctuated between hyposaline (but mostly exceeding about 10-15) and hypersaline modes. The numerous lithological changes present in this interval also attest to the shallow depths and oscillating environmental conditions of the Early Sarmatian. The Cpo-Cpl zonal boundary coincides with a hiatus that marks an important regression at the Badenian-Sarmatian boundary (Tari, 1992; Vakarcs et al., 1998; Harzhauser \& Piller, 2004a). This event seems to be related to the glacio-eustatic isotope event Mi-3 at 12.7 ma (Harzhauser \& Piller, 2004b) and corresponds to the TB. 2.6 sequence boundary of Haq et al. (1988). A probable total disconnection of marine seaways led to the isolation of the Paratethys during this time. Climatic cooling due to the increase in the development of the East Antarctic Ice Sheet (Flower \& Kennett, 1994) persisted into the Early Sarmatian. Later, during the Late Miocene and beyond the time span of these investigations, the basins examined became fully isolated from the adjacent oceans and a brackish to freshwater lake called Lake Pannon (Rögl, 1998) developed.

\section{ACKNOWLEDGEMENTS}

Fritz Steininger is thanked for introducing G.J.-M. to field exposures in the Vienna Basin, Austria. Jean-Pierre Suc and Laszló Kordos kindly organized the sampling of the Tengelic-2 borehole in Hungary. The authors are also grateful to A. Dulai, Derzsó Illés and Speranta M. Popescu for their help with the sampling, and to Maria Sutó-Széntai for providing additional core samples from this borehole. G.J.-M.'s research was funded by a PhD grant from the 'Junta de Andalucía', Spain and by the French Ministry of Research (cotutelle grant). Field trips to Hungary for sampling were supported by the CNRS and the Hungarian Academy of Sciences within the framework of a co-operative project led by P. Moissette and A. Dulai. The authors are indebted to the EEDEN Programme (ESF) for the opportunity to participate in several international workshops. Isabel Sánchez Almazo is thanked for her assistance with SEM 
photography at the CEAMA centre in Granada. H. Brinkhuis, P. Schiøler, L. Londeix and F. J. Gregory are thanked for their very helpful suggestions on the manuscript.

\section{COMMENTS ON SPECIFIC TAXA (M.J.H AND G.J.-M.)}

Achomosphaera sp., cf. A. andalousiensis Jan du Chêne, 1977, emend. Jan du Chêne \& Londeix, 1988 (Pl. 8, figs 8-12). This morphotype was first described from Germany by Strauss (in Srauss \& Lund, 1992) and Strauss et al. (2001, fig. 3). Each specimen bears a few processes with welldeveloped distal fenestrations, although more such processes occur on the type material (Jan du Chêne, 1977; Jan du Chêne \& Londeix, 1988). Achomosphaera cf. andalousiensis has a range base within zone Naq (late Langhian to earliest Serravallian) in northern Germany (as Spiniferites cf. andalousiensis in Strauss et al., 2001) and is restricted to the late Langhian (Early Badenian) of the present study, whereas Achomosphaera andalousiensis is regarded as having a lowest occurrence within the upper Middle Miocene (e.g. Powell, 1986b).

Cerebrocysta 'cassinascoensis' Zevenboom \& Santarelli in Zevenboom, 1995 (Pl. 1, figs 7-9). The few specimens recorded in the present study compare favourably with this species as described from the Miocene of Italy (Zevenboom \& Santarelli in Zevenboom, 1995). Cerebrocysta 'cassinascoensis' was considered a manuscript name by the authors.

Cerebrocysta poulsenii de Verteuil \& Norris, 1996 (Pl. 1, figs $10-12)$. Specimens vary in the extent to which tabulation is expressed by crests on the central body (see also de Verteuil \& Norris, 1996), although most show conspicuous tabulation (e.g. Pl. 1, figs 10-12).

Glaphyrocysta reticulosa (Gerlach, 1961) Stover \& Evitt, 1978 sensu lato (Pl. 5, figs 1-10; Pl. 9, fig. 11). Specimens are dorso-ventrally compressed and processes are concentrated around the ambitus where they are longest, although may also occur in the mid-ventral area (e.g. Pl. 5, figs 1-5). Processes vary from solid and thin (e.g. Pl. 5, figs $1-5$, which is similar to the type material), to robust and funnel-shaped (e.g. Pl. 5, figs 6-10) and are distally connected by irregular strands and patches of thin ectophragm, often with perforations. Process bases show occasional weak alignment into arcuate process complexes. Stover \& Evitt (1978) assigned this species questionably to their genus Glaphyrocysta on the basis that the distribution of processes is uncertain. In the current material, the degree to which process distribution reflects tabulation is weak but variable, and this is not therefore considered a primary criterion of importance for defining the genus. Consequently, Glaphyrocysta reticulosa is accepted as an unquestionable member of the genus.

Membranophoridium sp. (Pl. 5, figs 11, 12). Specimens differ from Glaphyrocysta reticulosa s.1. in having such reduced processes that the ectophragm may arise directly from the central body wall. More detailed morphological studies are needed to determine whether Membranophoridium sp. is a reduced-process morphotype of Glaphyrocysta reticulosa s.1.

Nannbarbophora gedlii Head, 2003 (Pl. 2, figs 14-16; Pl. 9, fig. 1). Records from the Middle Ottnangian (mid-Burdigalian) through Upper Badenian (lower Serravallian) of this study confirm that this acritarch species has a stratigraphic range of at least Early through Middle Miocene (Head, 2003).

Operculodinium centrocarpum-israelianum (Pl. 7, figs 4, 5). Specimens here designated belong to either Operculodinium centrocarpum sensu stricto or Operculodinium israelianum or to similar morphotypes (see Head, 1996, pp. 553, 556 for discussion).

Palaeocystodinium powellii Strauss et al., 2001 (P1. 8, fig. 13). The name Palaeocystodinium powellense Strauss et al., 2001 is here treated as an orthographic error and corrected to Palaeocystodinium powellii because it commemorates the person A. J. Powell, and not a place (Greuter et al., 2000, Art. 60.11). Calcareous cyst linings ( $\mathrm{Pl}$. 2, figs 6-8). These are considered to be the organic linings of the walls of calcareous dinoflagellate cysts and are probably produced by species of the extant genus Scrippsiella Balech, 1959, emend. Janofske, 2000. Specimens are thin walled, inconspicuous, approximately spherical to broadly ovoidal and often have a very faintly reticulated surface that apparently reflects the calcareous ornament on the outer cyst wall. The archaeopyle, where observed clearly, involves displacement of at least the apical plates but possibly also the intercalary series, and the operculum remains attached ventrally (Pl. 2, figs 6-8; see Lewis, 1991, figs 9c, $48 \mathrm{a}-\mathrm{c})$. The consistent presence of specimens throughout the Baden-Sooss section and Tengelic-2 borehole supports the contention by Head et al. (2006) that the organic linings of calcareous cysts are more common in the palynological record than previously realized.

\section{Manuscript received 26 July 2005 Manuscript accepted 29 May 2006}

\section{REFERENCES}

Allen, P.A. \& Homewood, P. 1984. Evolution and mechanics of a Miocene tidal sandwave. Sedimentology, 31: 63-81.

Balech, E. 1959. Two new genera of dinoflagellates from California. The Biological Bulletin, 116: 195-203.

Baltes, N. 1967. Microflora from Miocene salt-bearing formation of the pre-Carpathian depression (Rumania). Review of Palaeobotany and Palynology, 2: 183-194.

Baltes, N. 1969. Distribution stratigraphique des dinoflagellés et des acritarches tertiaires en Roumanie. In: Brönnimann, P. \& Renz, H.H. (Eds), International Conference on Planktonic Microfossils, Geneva, 1967, Proceedings, 1. E.J. Brill, Leiden, The Netherlands, 26-45.

Benedek, P.N. \& Sarjeant, W.A.S. 1981. Dinoflagellate cysts from the middle and upper Oligocene of Tönisberg (Niederrheingebiet): a morphological and taxonomic restudy. Nova Hedwigia, 35: 313-356.

Berggren, W.A., Kent, D.V. \& Swisher, C.C. III. 1995. A revised Cenozoic geochronology and chronostratigraphy. In: Berggren, W.A., Kent, D.V., Aubry, M.-P. \& Hardenbol, J. (Eds), Geochronology, time scales and global stratigraphic correlation. Society of Economic Paleontologists and Mineralogists, Special Publication, 54: 129-212.

Bertini, A., Londeix, L., Maniscalco, R., et al. 1998. Paleobiological evidence of depositional conditions in the Salt Member, GessosoSolfifera Formation (Messinian, Upper Miocene) of Sicily. Micropaleontology, 44: 413-433.

Biffi, U. \& Manum, S.B. 1988. Late Eocene-Early Miocene dinoflagellate cyst stratigraphy from the Marche Region (Central Italy). Bolletino della Società Paleontologica Italiana, 27 (2): 163-212.

Bohn-Havas, M. 1982. Mollusca fauna of Badenian and Sarmatian stages from the borehole Tengelic 2. In: Nagy, E., Bodor, E., Nagymarosy, A., et al. (Eds), Palaeontological examination of the geological log of the borehole Tengelic 2. Annales Instituti Geologici Publici Hungarici, 65: 200-203. 
Brinkhuis, H. 1994. Late Eocene to early Oligocene dinoflagellate cysts from the Priabonian type-area (northeast Italy); biostratigraphy and palaeoenvironmental interpretation. Palaeogeography, Palaeoclimatology, Palaeoecology, 107: 121-163.

Brinkhuis, H., Powell, A.J. \& Zevenboom, D. 1992. High resolution dinoflagellate cyst stratigraphy of the Oligocene/Miocene transition interval in northwest and central Italy. In: Head, M.J. \& Wrenn, J.H (Eds), Neogene and Quaternary dinoflagellate cysts and acritarchs. American Association of Stratigraphic Palynologists Foundation, Dallas, Texas, 219-258.

Corradini, D. 1989. Dinocisti tortoniane nella formazione terravecchia. 'Igessi di Santa Ninfa' studio multidisciplinare di un'area carsica. Memoire dell'Istituto Italiano dí Speleologia, II, 3: 185-189.

Costa, L.I. \& Downie, C. 1979. Cenozoic dinocyst stratigraphy of Sites 403 to 406 (Rockall Plateau), IPOD, Leg 48. In: Montadert, L., Roberts, D.G., et al. (Eds), Initial Reports of the Deep Sea Drilling Project, 48. US Government Printing Office, Washington D.C, 513-529.

Dale, B. 1996. Dinoflagellate cyst ecology: modelling and geological applications. In: Jansonius, J. \& McGregor, D.C. (Eds), Palynology: Principles and applications, 3. American Association of Stratigraphic Palynologists Foundation, Dalla, Texas, 1249-1275.

de Verteuil, L. 1996. Data report: Upper Cenozoic dinoflagellate cysts from the continental slope and rise off New Jersey. In: Mountain, G.S., Miller, K.G., Blum, P., et al. (Eds), Proceedings of the Ocean Drilling Program, Scientific Results, 150. Ocean Drilling Program, College Station, Texas, 439-454.

de Verteuil, L. 1997. Palynological delineation and regional correlation of Lower through Upper Miocene sequences in the Cape May and Atlantic City boreholes, New Jersey coastal plain. In: Miller, K.G. \& Snyder, S.W. (Eds), Proceedings of the Ocean Drilling Program, Scientific Results, 150X. Ocean Drilling Program, College Station, Texas, 129-145.

de Verteuil, L. \& Norris, G. 1996. Part 1. Dinoflagellate cyst zonation and allostratigraphy of the Chesapeake Group. In: de Verteuil, L. \& Norris, G. (Eds), Miocene dinoflagellate stratigraphy and systematics of Maryland and Virginia. Micropaleontology, 42 (supplement): 1-172.

Dybkjær, K. 2004. Dinocyst stratigraphy and palynofacies studies used for refining a sequence stratigraphic model - uppermost Oligocene to lower Miocene, Jylland, Denmark. Review of Palaeobotany and Palynology, 131: 201-249.

Dybkjær, K. \& Rasmussen, E.S. 2000. Palynological dating of the Oligocene-Miocene successions in the Lille Bælt area, Denmark. Bulletin of the Geological Society of Denmark, 47: 87-103.

El Beialy, S.Y. 1988. Palynostratigraphy of late Tertiary sediments in Kafr El-Dawar well No. 1, Nile Delta, Egypt. Revue de Micropaléontologie, 30 (4): 249-260.

El Beialy, S.Y. \& Ali, A.S. 2002. Dinoflagellates from the Miocene Rudeis and Kareem formations borehole GS-78-1, Gulf of Suez, Egypt. Journal of African Earth Sciences, 35: 235-245.

Faupl, P. \& Roetzel, R. 1987. Gezeitenbeeinflußte Ablagerungen der Innviertler Gruppe (Ottnangian) in oberösterreichischen Molassezone. Jahrbuch der Geologischen Bundesanstalt, 130 (4): 415-447.

Fensome, R.A. \& Williams, G.L. 2004. The Lentin and Williams index of fossil dinoflagellates: 2004 Edition. American Association of Stratigraphic Palynologists, Contributions Series, 42: 909 pp.

Flower, B. \& Kennett, J. 1994. The middle Miocene climatic transition: East Antarctic ice sheet development, deep ocean circulation and global carbon cycling. Palaeogeography, Palaeoclimatology, Palaeoecology, 108: 537-555.

Fornaciari, E., Di Stefano, A., Rio, D. \& Negri, A. 1996. Middle Miocene quantitative calcareous nannofossil biostratigraphy in the Mediterranean region. Micropaleontology, 42: 37-63.

Fuchs, R. \& Stradner, H. 1977. Über Nannofossilien im Badenien (Mittelmiozän) der Zentralen Paratethys. Beiträge zur Paläontologie von Österreich, 2: 1-58.

Gerlach, E. 1961. Mikrofossilien aus dem Oligozän und Miozän Nordwestdeutschlands, unter besonderer Berücksichtigung der Hystrichosphaeren und Dinoflagellaten. Neues Jahrbuch für Geologie und Paläontologie, Abhandlungen, 112: 143-228.
Gradstein, F.M., Ogg, J.G., Smith, A.G., Bleeker, W. \& Lourens, L.J. 2004. A new geologic time scale with special reference to Precambrian and Neogene. Episodes, 27: 83-100.

Greuter, W., McNeill, J., Barrie, F.R., et al. 2000. International Code of Botanical Nomenclature (Saint Louis Code). Regnum Vegetabile, 138: i-xviii, $1-474$.

Grill, R. 1941. Stratigraphische Untersuchungen mit Hilfe von Mikrofaunen im Wiener Becken und den benachbarten Molasse-Anteilen. Öl und Kohle, 37: 595-602.

Grill, R. 1943. Über mikropaläontologische Gliederungsmöglichkeiten im Miozän des Wiener Becken. Mitteilungen der Reichsanstalt für Bodenforschung, 6: 33-44.

Halmai, J., Jámbor, A., Ravasz-Baranyai, L. \& Vetö, I. 1982. Geological results of the borehole Tengelic-2. Annales Instituti Geologici Publici Hungarici, 65: 93-138.

Haq, B.U., Hardenbol, J. \& Vail, P.R. 1988. Mesozoic and Cenozoic chronostratigraphy and cycles of sea level changes. In: Wilgus, C.K., Hastings, B.S., Kendall, C.G.StC., Posamentier, H.W., Ross, C.A. \& Van Wagoner, J.C. (Eds), Sea-level changes - an integrated approach. Society of Economic Paleontologists and Mineralogists, Special Publication, 42: 71-108.

Harzhauser, M. \& Piller, W.E. 2004a. The Early Sarmatian - hidden seesaw changes. Courier Forschungsinstitut Senckenberg, 246: 89-112.

Harzhauser, M. \& Piller, W.E. 2004b. Integrated stratigraphy of the Sarmatian (Upper Middle Miocene) in the western Central Paratethys. Stratigraphy, 1: 65-86.

Harzhauser, M., Mandic, O. \& Zuschin, M. 2003. Changes in Paratethyan marine molluscs at the Early/Middle Miocene transition: diversity, palaeogeography and palaeoclimate. Acta Geologica Polonica, 53 (4): 323-339.

Head, M.J. 1996. Paleoecological and taxonomic revision of late Cenozoic dinoflagellates from the Royal Society borehole at Ludham, Norfolk, eastern England. Journal of Paleontology, 70 (4): 543-570.

Head, M.J. 2003. Neogene occurrences of the marine acritarch genus Nannobarbophora Habib and Knapp, 1982 emend., and the new species N. gedlii. Journal of Paleontology, 77 (2): 382-385.

Head, M.J. \& Westphal, H. 1999. Palynology and paleoenvironments of a Pliocene carbonate platform: the Clino Core, Bahamas. Journal of Paleontology, 73 (1): 1-25.

Head, M.J., Norris, G. \& Mudie, P.J. 1989a. Palynology and dinocyst stratigraphy of the Upper Miocene and lowermost Pliocene, ODP Leg 105, Site 646, Labrador Sea. In: Srivastava, S.P., Arthur, M., Clement, B., et al. (Eds), Proceedings of the Ocean Drilling Program, Scientific Results, 105. Ocean Drilling Program, College Station, Texas, 423-451.

Head, M.J., Norris, G. \& Mudie, P.J. 1989b. Palynology and dinocyst stratigraphy of the Miocene in ODP Leg 105, Hole 645E, Baffin Bay. In: Srivastava, S.P., Arthur, M., Clement, B., et al. (Eds), Proceedings of the Ocean Drilling Program, Scientific Results, 105. Ocean Drilling Program, College Station, Texas, 467-514.

Head, M.J., Lewis, J. \& de Vernal, A. 2006. The cyst of the calcareous dinoflagellate Scrippsiella trifida; resolving the fossil record of its organic wall and that of Alexandrium tamarense. Journal of Paleontology, 80 (1): 1-18.

Hochuli, P.A. 1978. Palynologische Untersuchungen im Oligozän und Untermiozän der Zentralen und Westlichen Paratethys. Beiträge zur Paläontologie von Österreich, 4: 1-132.

Hámor, G. 1995. Miocene palaeogeographic and facies map of the Carpathian Basin. Eötvös Lorand University, Budapest, Hungary.

Jan du Chêne, R. 1977. Étude palynologique du Miocène supérieur Andalou (Espagne). Revista Española de Micropaleontología, 9: 97-114.

Jan du Chêne, R. \& Londeix, L. 1988. Données nouvelles sur Achomosphaera andalousiense Jan du Chêne, 1977, kyste de dinoflagellé fossile. Bulletin des Centres de recherches exploration-production Elf-Aquitaine, 12 (1): 237-250.

Janofske, D. 2000. Scrippsiella trochoidea and Scrippsiella regalis, nov. comb. (Peridiniales, Dinophyceae): a comparison. Journal of Phycology, 36: 178-189.

Jiménez-Moreno, G., Rodríguez-Tovar, F.J., Pardo-Igúzquiza, E., Fauquette, S., Suc, J.-P. \& Müller, P. 2005. High-resolution palyno- 
logical analysis in late early-middle Miocene core from the Pannonian Basin, Hungary: climatic changes, astronomical forcing and eustatic fluctuations in the Central Paratethys. Palaeogeography, Palaeoclimatology, Palaeoecology, 216: 73-97.

King, C. 1989. Cenozoic of the North Sea. In: Jenkins, D.G. \& Murray, J.W. (Eds), Stratigraphical atlas of fossil foraminifera (second edition). British Micropalaeontological Society Publication. Ellis Horwood Limited, Chichester, 418-489.

Korecz-Laky, I. 1982. Miocene foraminifera fauna from the borehole Tengelic 2. In: Nagy, E., Bodor, E., Nagymarosy, A., et al. (Eds), Palaeontological examination of the geological log of the borehole Tengelic 2. Annales Instituti Geologici Publici Hungarici, 65: 186-187.

Kovac, M., Barath, I., Harzhauser, M., Hlavaty, I. \& Hudackova, N. 2004. Miocene depositional systems and sequence stratigraphy of the Vienna Basin. Courier Forschungsinstitut Senckenberg, 246: 187-212.

Kókay, J. 1996. Stratigraphical analysis of Badenian sections from western Hungary (Transdanubia) compared to the eustatic sea-level changes [in Hungarian, with English abstract]. Földtani Közlöny, 126: 97-115.

Köthe, A. 2004. Dinozysten-Untersuchungen eines unter-miozänen Glaukonitsandes in der Ziegeleitongrube OLFRY/Vechta (Niedersachsen). Neues Jahrbuch für Geologie und Paläontologie Monatshefte, 2004 (5): 257-277.

Laursen, G.V. \& Kristoffersen, F.N. 1999. Detailed foraminiferal biostratigraphy of Miocene Formations in Denmark. Mededelingen van de Werkgroep voor Tertiaire en Kwartaire Geologie, 36: 73-107.

Lesueur, J.-P., Rubino, J.-L. \& Giraudmaillet, M. 1990. Organisation et structures internes des dépôts tidaux du Miocène rhodanien. Bulletin de la Société Géologique de France, 6 (1): 49-65.

Lewis, J. 1991. Cyst-theca relationships in Scrippsiella (Dinophyceae) and related orthoperidinioid genera. Botanica Marina, 34: 91-106.

Londeix, L. \& Jan du Chêne, R. 1998. Burdigalian dinocyst stratigraphy of the stratotypic area (Bordeaux, France). Geobios, 30: 283-294.

Louwye, S. 2001. New species of dinoflagellate cysts from the Berchem Formation, Miocene, northern Belgium (southern North Sea Basin). Geobios, 34: 121-130.

Louwye, S. \& Laga, P. 1998. Dinoflagellate cysts of the shallow marine Neogene succession in the Kalmthout well, northern Belgium. Bulletin of the Geological Survey of Denmark, 45: 73-86.

Louwye, S., De Coninck, J. \& Verniers, J. 2000. Shallow marine Lower and Middle Miocene deposits at the southern margin of the North Sea Basin (northern Belgium): dinoflagellate cyst biostratigraphy and depositional history. Geological Magazine, 137: 381-394.

MacLean, J.L. 1989. An overview of Pyrodinium red tides in the Western Pacific. In: Hallegraeff, G.M. \& Maclean, J.L. (Eds), Biology, epidemiology and management of Pyrodinium red tides. ICLARM Conference Proceedings, 21. International Center for Living Aquatic Resources Management, Manila, Philippines, 1-7.

Manum, S.B., Boulter, M.C., Gunnarsdottir, H., Rangnes, K. \& Scholze, A. 1989. Eocene to Miocene palynology of the Norwegian Sea (ODP Leg 104). In: Eldholm, O., Thiede, J., Taylor, E., et al. (Eds), Proceedings of the Ocean Drilling Program, Scientific Results, 104. Ocean Drilling Program, College Station, Texas, 611-662.

Martel, A.T., Allen, P.A. \& Slingerland, R. 1994. Use of tidalcirculation modelling in paleogeographical studies: An example from the Tertiary of the Alpine perimeter. Geology, 22: 925-928.

Martini, E. \& Worsley, T. 1970. Standard Neogene calcareous nannoplankton zonation. Nature, 225 (5229): 289-290.

Meulenkamp, J.E. \& Sissingh, W. 2003. Tertiary palaeogeography and tectonostratigraphic evolution of the Northern and Southern PeriTethys platforms and the intermediate domains of the AfricanEurasian convergent plate boundary zone. Palaeogeography, Palaeoclimatology, Palaeoecology, 196 (1-2): 209-228.

Montanari, A., Bice, D.M., Capo, R., et al. 1997. Chapter C3. Integrated stratigraphy of the Chattian to mid-Burdigalian pelagic sequence of the Contessa Valley (Gubbio, Italy). In: Montanari, A., Odin, G.S. \& Coccioni, R. (Eds), Miocene stratigraphy: An integrated approach. Elsevier, Amsterdam, 249-277.

Nagymarosy, A. 1982. Badenian-Sarmatian nannoflora from the borehole Tengelic 2. In: Nagy, E., Bodor, E., Nagymarosy, A., et al. (Eds), Palaeontological examination of the geological log of the borehole Tengelic 2. Annales Instituti Geologici Publici Hungarici, 65: 145-149.
Papp, A. \& Steininger, F. 1978. Holostratotypus: Baden-Sooss. In: Papp, A., Cicha, I., Senes, J. \& Steininger, F. (Eds), M4-Badenien (Moravien, Wielicien, Kosovien). Chronostratigraphie und Neostratotypen, 6: 158-168.

Piasecki, S. 1980. Dinoflagellate cyst stratigraphy of the Miocene Hodde and Gram Formations, Denmark. Geological Society of Denmark Bulletin, 29: 53-76.

Powell, A.J. 1986a. Latest Palaeogene and Earliest Neogene dinoflagellate cysts from the Lemme section, Northwest Italy. In: Wrenn, J.H., Duffield, S.L. \& Stein, J.A. (Eds), Papers from the first symposium on Neogene dinoflagellate cyst biostratigraphy. American Association of Stratigraphic Palynologists Contributions Series, 17: 83-104.

Powell, A.J. 1986b. A dinoflagellate cyst biozonation for the Late Oligocene to Middle Miocene succession of the Langhe region, Northwest Italy. In: Wrenn, J.H., Duffield, S.L. \& Stein, J.A. (Eds), Papers from the first symposium on Neogene dinoflagellate cyst biostratigraphy. American Association of Stratigraphic Palynologists Contributions Series, 17: 105-127.

Royden, L.H. 1985. The Vienna Basin: a thin-skinned pull-apart basin. In: Biddle, K.T. \& Christie-Blick, N. (Eds), Strike-slip deformation basin formation and sedimentation. Society of Economic Paleontologists and Mineralogists, Special Publication, 37: 319-338.

Royden, L.H. \& Horváth, F. 1988. The Pannonian Basin. A study in basin evolution. American Association of Petroleum Geologists, Memoir, 45: 394 pp.

Rupp, C., Roetzel, R. \& Stojaspal, F. 1996. Stop 9: Strass-Eberschwang. In: Krenmayr, H.G. \& Roetzel, R. (Eds), Oligozäne und miozäne Becken- und Gezeitensedimente in der Molassezone Oberösterreichs. Exkursionsführer des 11. Sedimentologentreffen. Berichte der Geologischen Bundesanstalt, 33: 25-27.

Rusbült, J. \& Strauss, C. 1992. Mikrofossilien des Unter-und Mittelmiozän in der Braunkohlenbohrung Lübtheen 46/84 (südwestMecklenburg). Neues Jahrbuch für Geologie und Paläontologie, Monatshefte, 3: 150-170.

Rögl, F. 1998. Palaeogeographic considerations for Mediterranean and Paratethys seaways (Oligocene to Miocene). Annalen des Naturhistorischen Museums in Wien, 99A: 279-310.

Rögl, F., Spezzaferri, S. \& Coric, S. 2002. Micropaleontology and biostratigraphy of the Karpatian-Badenian transition (Early-Middle Miocene boundary) in Austria (Central Paratethys). Courier Forschungsinstitut Senckenberg, 237: 47-67.

Schiøler, P. 2005. Dinoflagellate cysts and acritarchs from the Oligocene-Lower Miocene interval of the Alma-1X well, Danish North Sea. Journal of Micropalaeontology, 24: 1-37.

Shevenell, A.E., Kennett, J.P. \& Lea, D.W. 2004. Middle Miocene Southern Ocean cooling and Antarctic cryosphere expansion. Science, 305: 1766-1770.

Sluijs, A., Pross, J. \& Brinkhuis, H. 2005. From greenhouse to icehouse; organic-walled dinoflagellate cysts as paleoenvironmental indicators in the Paleogene. Earth-Science Reviews, 68: 281-315.

Steininger, F.F., Bernor, R. \& Fahlbusch, V. 1990. European Neogene marine/continental chronologic correlations. In: Lindsay, E.H., Fahlbusch, V. \& Mein, P. (Eds), European Neogene Mammal Chronology. NATO ASI Series A. Plenum, New York, 15-46.

Steininger, F.F., Berggren, W.A., Kent, D.V., Bernor, R.L., Sen, S. \& Agusti, J. 1996. Circum-Mediterranean Neogene (Miocene and Pliocene) marine-continental chronologic correlations of European mammal units. In: Bernor, R.L., et al. (Eds), The evolution of western Eurasian Neogene mammal faunas. Columbia University Press, New York, 7-46.

Stover, L.E. \& Evitt, W.R. 1978. Analyses of pre-Pleistocene organicwalled dinoflagellates. Stanford University Publications, Geological Sciences, 15: $300 \mathrm{pp}$.

Stover, L.E., Brinkhuis, H., Damassa, S.P., et al. 1996. MesozoicTertiary dinoflagellates, acritarchs and prasinophytes. In: Jansonius, J. \& McGregor, D.C. (Eds), Palynology: Principles and applications, 2. American Association of Stratigraphic Palynologists Foundation, Dallas, Texas, 641-750.

Strauss, C. \& Lund, J. 1992. A Middle Miocene dinoflagellate cyst microflora from Papendorf near Hamburg, Germany. Mitteilungen, Geologisch-Paläontologisches Institut, Universität Hamburg 73: $159-189$. 
Strauss, C., Lund, J.J. \& Lund-Christensen, J. 2001. Miocene dinoflagellate cyst biostratigraphy of the Nieder Ochtenhausen Research Borehole (NW Germany). Geologisches Jahrbuch, A152: 395-447.

Suc, J.-P., Londeix, L., Poumot, C., et al. 1995. Evolution of the Messinian Mediterranean environments - the Tripoli Formation at Capodarso (Sicily, Italy). Review of Palaeobotany and Palynology, 87 (1): $51-79$

Sütó-Szentai, M. 1994. Microplankton associations of organic skeleton in the surroundings of Villány Mts. Földtani Közlöny, 124 (4): $451-478$.

Sütó-Szentai, M. 1995. Délkelet-Dunántúl ósföldrajzi képe a Pannoniai emelet idején. Folia Comloensis, 6: 35-55.

Sütó-Szentai, M. 2002. Analysis of microplankton of organic skeleton from borehole Nagykozár-2 (S-Hungary). Folia Comloensis, 11: 93-110.

Sütó-Szentai, M. 2003. The organic-walled microplankton in borehole Máriakéménd-3 (Southern Hungary). Folia Comloensis, 12: 129-142.

Tari, G. 1992. Late Neogene transgression in the northern thrust zone Mecsek Mts, Hungary. Annales Eötvös University Budapest, Sect. Geol., 29: 165-187.

Torricelli, S. \& Biffi, U. 2001. Palynostratigraphy of the Numidian Flysch of northern Tunisia (Oligocene-Early Miocene). Palynology, 25: 29-56.

Vakarcs, G., Hardenbol, J., Abreu, V.S., Vail, P.R., Várnai, P. \& Tari, G. 1998. Oligocene-Middle Miocene depositional sequences of the Central Paratethys and their correlation with regional stages. In: Graciansky, P.-C. de, Hardenbol, J., Jacquin, T. \& Vail, P.R. (Eds), Mesozoic and Cenozoic sequence stratigraphy of European basins.
Society of Economic Paleontologists and Mineralogists, Special Publication, 60: 209-231.

Wessely, G. 1988. Structure and development of the Vienna Basin in Austria. In: Royden, L.H. \& Horvath, F. (Eds), The Pannonian System. A study in basin evolution. American Association of Petroleum Geologists Memoirs, 45: 333-346.

Williams, G.L., Brinkhuis, H., Pearce, M.A., Fensome, R.A. \& Weegink, J.W. 2004. Southern Ocean and global dinoflagellate cyst events compared: Index events for the Late Cretaceous-Neogene. In: Exon, N.F., Kennett, J.P. \& Malone, M.J. (Eds), Proceedings of the Ocean Drilling Program, Scientific Results, 189. Ocean Drilling Program, College Station, Texas, 1-98.

Wilpshaar, M., Santarelli, A., Brinkhuis, H. \& Visscher, H. 1996. Dinoflagellate cysts and mid-Oligocene chronostratigraphy in the central Mediterranean region. Journal of the Geological Society, London, 153: 553-561.

Zevenboom, D. 1995. Dinoflagellate cysts from the Mediterranean Late Oligocene and Miocene. PhD thesis. State University of Utrecht and CIP-Gegevens Koninklijke Bibliotheek, Den Haag, 221 pp.

Zevenboom, D. 1996. Late Oligocene-early Miocene dinoflagellate cysts from the Lemme-Carrosio section (NW Italy); biostratigraphy and palaeoenvironmental interpretation. Giornale di Geologia, ser. 3, 58 (1-2): 81-93.

Zevenboom, D., Brinkhuis, H. \& Visscher, H. 1994. Dinoflagellate cysts [sic.] palaeoenvironmental analysis of the Oligocene/Miocene transition in northwest and central Italy. Giornale di Geologia, ser. 3, 56(1): $155-169$. 